\title{
M. du Bois-Reymond goes to Paris
}

\author{
GABRIEL FINKELSTEIN*
}

\begin{abstract}
This article examines the science of electrophysiology developed by Emil du BoisReymond in Berlin in the 1840s. In it I recount his major findings, the most significant being his proof of the electrical nature of nerve signals. Du Bois-Reymond also went on to detect this same 'negative variation', or action current, in live human subjects. In 1850 he travelled to Paris to defend this startling claim. The essay concludes with a discussion of why his demonstration failed to convince his hosts at the French Academy of Sciences.
\end{abstract}

La science ne consiste pas en faits, mais dans les conséquences que l'on en tire.

Claude Bernard, Introduction à l'étude de la médicine expérimentale

Good talkers are only found in Paris.

François Villon, Des Femmes de Paris

Walter Benjamin called Paris the capital of the nineteenth century. To the Berlin physiologist Emil du Bois-Reymond, Paris was also the capital of nineteenth-century science. For a combination of significance, concentration and glamour, no city in 1849 rivalled its institutions and facilities. The French metropolis was the Broadway of scientific performance, and everyone knew that reputations remained incomplete without its notice. 'As soon as you get your book out', his teacher Gustav Magnus once advised him,

pack up your shop, multiplier, and all your apparatus, take twenty copies with you, go to Paris, let a small, quiet room near the Jardin des Plantes, bombard them with your book, and be impertinent until you get those fellows in your room. Then lock the door, put the key in your pocket, and demonstrate away. ${ }^{1}$

* Department of History, University of Colorado at Denver, PO Box 173364, Denver, Colorado 802173364, USA.

Versions of this paper were presented in 1997 to the Center for Cultural Studies of Science, Technology, and Medicine at UCLA and in 1998 to the Department of History of Science at Harvard University, and I am glad of suggestions offered there. I am obliged to the librarians and archivists at the Staatsbibliothek Preußischer Kulturbesitz zu Berlin, the Staats- und Universitätsbibliothek Göttingen, the New York Public Library, the Firestone Library at Princeton University and the Crear Library at the University of Chicago for allowing me access to their holdings. I would also like to thank David Barrett for helping me reformat my notes and Bill MacCallum and Brom Kim for scanning illustrations. I would also like to thank David Cahan, Nicolaas Rupke, Kathy Olesko, Andre Wakefield and Margaret Rossiter for their encouragement. Finally, I wish to dedicate this essay to the memory of my advisor, Gerald L. Geison, a great scholar and a sensitive man.

1 Sowie Sie mit dem Druck fertig sind, packen Sie Ihre ganze Wirtschaft, Multiplikator nebst Zubehör usw. ein, nehmen 20 Freiexemplare mit, gehen nach Paris, nehmen ein rubiges Stübchen beim Pflanzengarten, bombardieren mit Ihrem Buch und sind unverschämt bis Sie die Kerle auf Ibrer Stube haben. Dann schließen Sie ab, stecken den Schlüssel in die Tasche und experimentiren ibnen vor. 


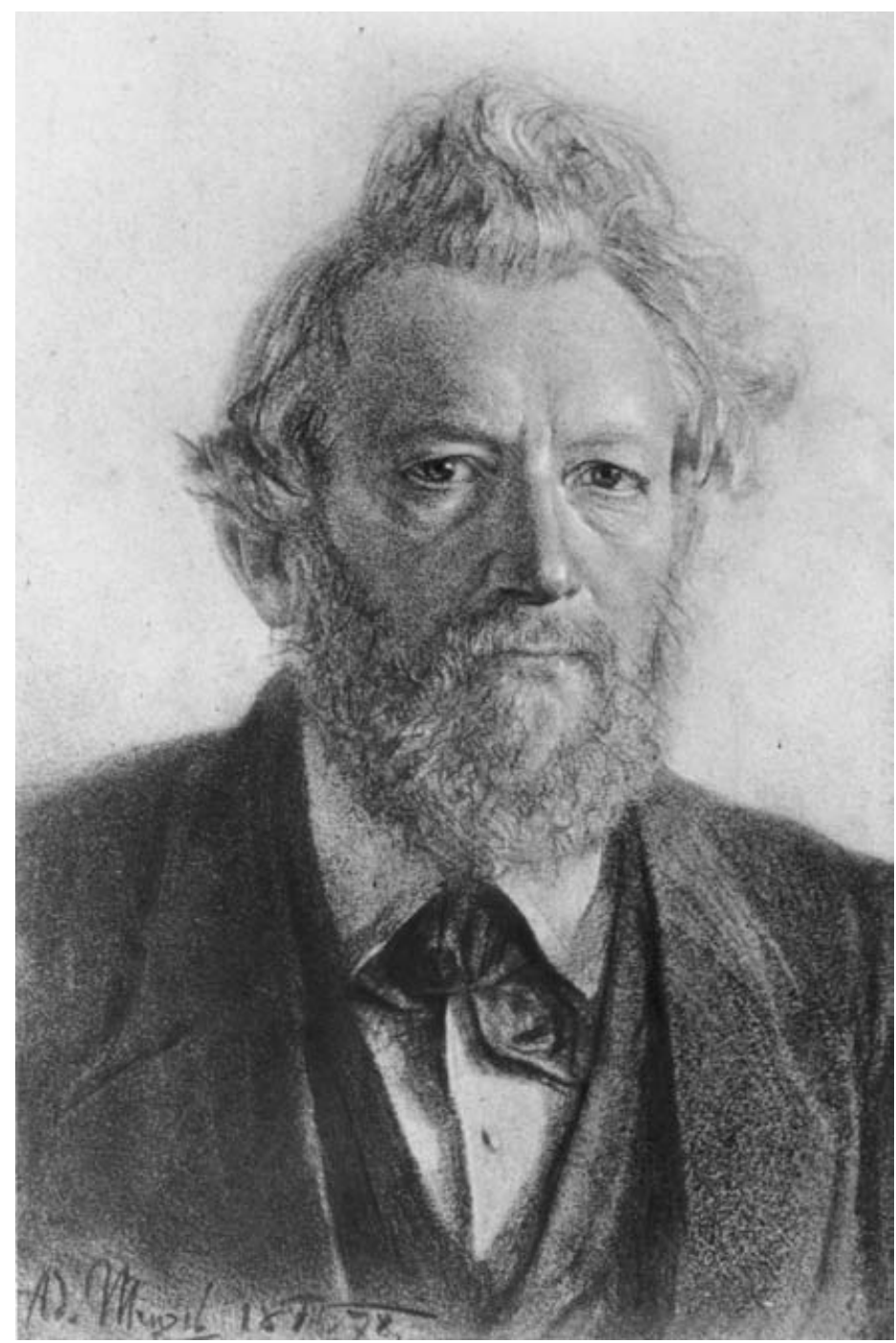

Figure 1. Portrait of Emil du Bois-Reymond.

What follows is the story of du Bois-Reymond's encounter with Parisian science, a debacle so great that it soured relations between French and German physiologists for over a generation. This tale can serve as a classic case of scientific controversy, one displaying all the requisite elements of pride, misunderstanding and bitterness. It can

E. du Bois-Reymond, Jugendbriefe von Emil du Bois-Reymond an Eduard Hallmann. Zu seinem hundertsten Geburtstag dem 7 November 1918 herausgegeben von Estelle du Bois-Reymond, Berlin, 1918, 17. Juni 1846, 125-7, 126-7. Magnus felt that he had been too shy his first time in Paris. Gustav Magnus to Jacob Berzelius, 28 Februar 1829, Aus Jac. Berzelius' und Gustav Magnus' Briefwechsel in den Jahren 1828-1847 (ed. E. Hjelt), Braunschweig, 1900, 10-13. 


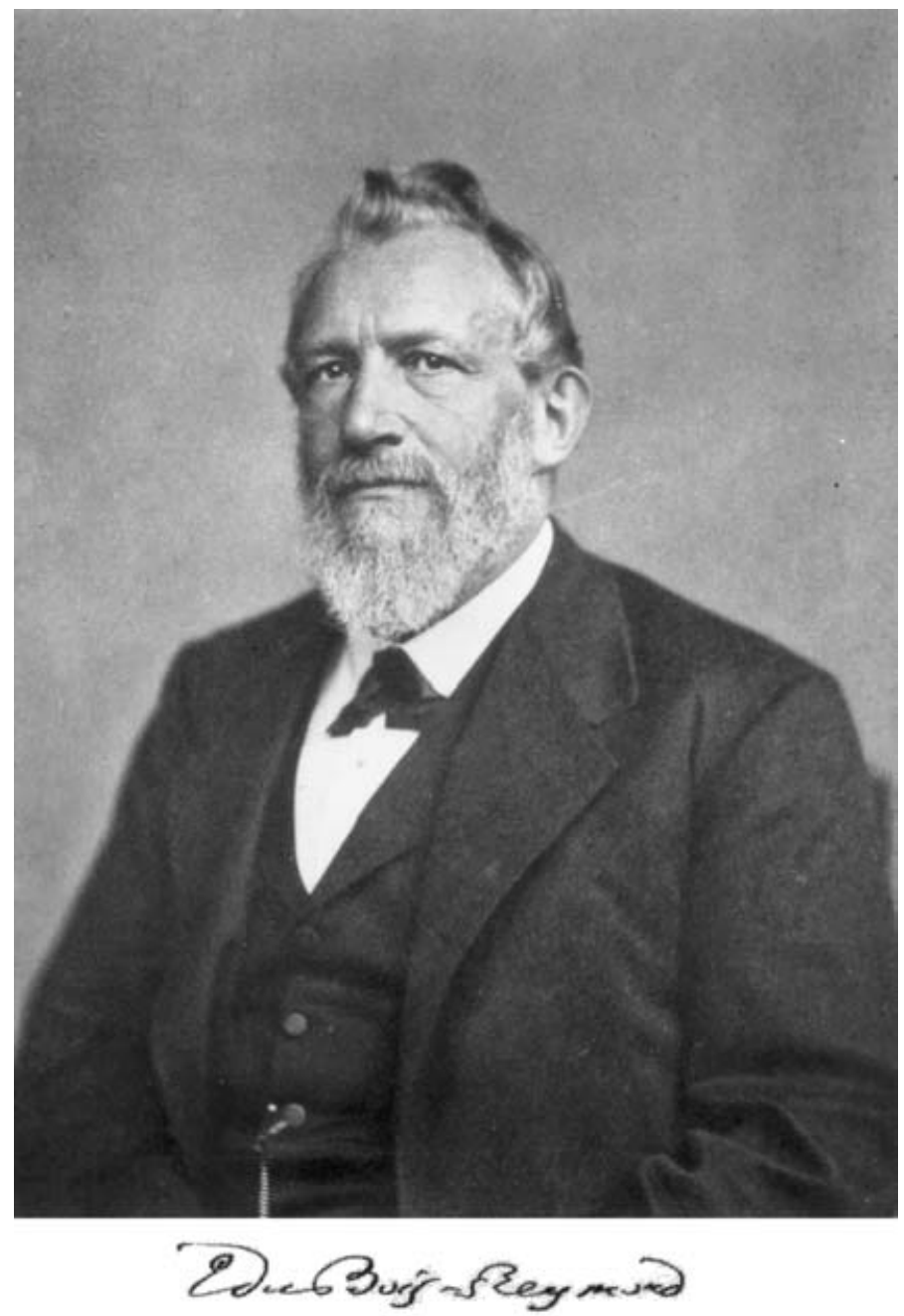

Figure 2. Photographic portrait of Emil du Bois-Reymond.

also be read as a drama of larger historical issues, one in which science acts as proxy for conflicts in national value. At the very least, it should remind us that facts in biology depend on context, and context always remains subject to interpretation.

\section{Background: Berlin}

Emil du Bois-Reymond's star has fallen a long way since the nineteenth century, when his portrait could be seen for sale in the shop windows of Berlin next to those of Helmholtz, Mommsen, Virchow, Bismarck and the royal family. ${ }^{2}$ Nevertheless, du

2 J. Laforgue, Berlin: The City and the Court (tr. W. J. Smith), New York, 1996, 166. The following biographical section borrows from my essay 'The ascent of man? Emil du Bois-Reymond's reflections on scientific progress', Endeavour: Review of the Progress of Science (2000), 24, 129-32. 
Bois-Reymond is an extremely important figure to historians of science as one of those rare figures who moved with equal ease between laboratory and podium. He was born into the Bildungsbürgertum, that elite and somewhat anxious social class central to discussions of modern German culture. His parents were about as well established as was possible for Bürger in Biedermeier Berlin; his father, a poor Swiss Huguenot, had worked his way through the ranks of the foreign office until he became court counsellor for the affairs of Neuchâtel, a position that he held until his early retirement in 1848 when revolution gained the canton independence from the Prussian crown. Du BoisReymond's mother had even better credentials. She was born into one of the oldest and most prominent of Berlin's Huguenot families. Her great-great-grandfather had been the city's first established silk dyer ${ }^{3}$ her grandfather was director of Berlin's Academy of Fine Arts and the city's most famous engraver $;^{4}$ and her father was pastor of the French church, librarian to the king and director of the state artists' guild. With such breeding du Bois-Reymond received an outstanding education, accompanying his father in Switzerland on official tours of inspection, learning to draw from his aunt, ${ }^{\mathbf{5}}$ polishing his French style at home and mixing with the wide circle of his family's friends and relations. He attended the Französische Gymnasium and the University of Berlin, where he studied a broad range of academic subjects before switching to the faculty of medicine in his sixth semester. In 1841 his advisor Johannes Müller asked him to look into Carlo Matteucci's treatise on animal electricity. This he did. In fact, du BoisReymond spent the rest of his scientific life looking into the topic. The first two volumes of his Investigations in Animal Electricity appeared in 1848 and 1849 and ran over 1400 pages; in 1884 he published a third volume to this truncated masterpiece. ${ }^{6}$ This research established electrophysiology as a scientific discipline; it also made his career, earning him a seat in the Prussian Academy of Sciences (1851), a professorship in physiology at the University of Berlin (1858) and Directorship of Berlin's first Institute of Physiology (1877). Nearly all this academic success, however, rested on experiments that he conducted between 1841 and 1851 . Let us turn to that initial decade of scientific productivity.

\section{Early work in electrophysiology: the 'Preliminary abstract' (1843)}

The key to understanding du Bois-Reymond's innovation lies in his instruments. ${ }^{7}$ Chief among these was the galvanometer, a device invented shortly after Oersted's discovery

3 Étienne Henry.

4 Daniel Chodowiecki.

5 Susette Henry.

6 E. du Bois-Reymond, Untersuchungen über thierische Elektricität, 2 vols., Berlin, 1848-84.

$7 \mathrm{Du}$ Bois-Reymond's science is treated by Otto Merkelbach, 'Zur Entwicklung der Beobachtung der aktiven elektrischen Erscheinungen im tierischen und menschlichen Körper', in Festschrift für Jacques Brodbeck-Sandreute ... zu seinem 60. Geburtstag 18 Juni 1942 (ed. K. Reucher), Basel, 1942, 271-97; M. A. B. Brazier, '[The] Rise of Physiology in the 19th Century', Journal of Neurophysiology (1959), 20, 212-26, 214-18; K. E. Rothschuh, 'Emil du Bois-Reymond (1818-1896) und die Elektrophysiologie der Nerven', in Von Boerhaave bis Berger. Die Entwicklung der kontinentalen Physiologie im 18. und 19. Jabrhundert mit besonderer Berücksichtigung der Neurophysiologie. Vorträge des Internationalen Symposiums zu Münster/Westfalia 18-20 September 1962 (ed. K. E. Rothschuh), Stuttgart, 1964, 85-105; C. von 
in 1819 that electric currents move magnets. ${ }^{8}$ The galvanometer worked very simply: a magnetized needle was allowed to pivot within a coil of wire. If electricity flowed in the wire, the needle swung. Additional turns of wire surrounding the needle multiplied the effect. In theory, the instrument could be made as sensitive as desired, the main limitations being the expense of purchasing ever longer spools of unbroken copper and the tedium of winding thousands of turns around a frame. In practice, two sources of unwanted magnetism interfered with the galvanometer's performance. One was the field of the Earth, which could be compensated by suspending a second needle in reversed orientation over the first. The other was the field produced by traces of iron in the coils, which could be corrected by placing a small magnet near the zero point of the needle's swing or, as du Bois-Reymond preferred, at the tip of the needle itself. On the whole these adjustments freed the instrument of spurious responses, rendering it 'astatic'. 9

Astatic galvanometers had been used in the investigation of animal electricity since 1827, but to ensure his expertise with them, du Bois-Reymond studied Carlo Matteucci's report, conversed with Heinrich Wilhelm Dove, his teacher of experimental physics, and practised with an instrument owned by Johannes Müller. ${ }^{10}$ The effort paid off.

Campenhausen, 'Elektrophysiologie und physiologische Modellvorstellungen bei Emil du Bois-Reymond', in Naturwissen und Erkenntnis im 19. Jahrhundert: Emil Du Bois-Reymond (ed. G. Mann), Hildesheim, 1981, 79-104; T. Lenoir, 'Models and instruments in the development of electrophysiology', Historical Studies in the Physical and Biological Sciences (1986), 17, 1-54; E. Clarke and L. S. Jacyna, Nineteenth-Century Origins of Neuroscientific Concepts, Berkeley, Los Angeles, London, 1987, 196-211; and Briefwechsel zwischen Alexander von Humboldt und Emil du Bois-Reymond (ed. I. Schwarz and K. Wenig), Berlin, 1997, 38-48.

$8 \mathrm{H}$. Christian Oersted, Experimenta Circa Effectum Conflictus Electrici In Acum Magneticam, Copenhagen, 1820, reprinted in G. Sarton, 'The foundation of electromagnetism', Isis (1928), 10, 435-44; B. Dibner, Oersted and the Discovery of Electromagnetism, 2nd edn (first published Norwalk, 1961), New York, 1962, 31; J. S. C. Schweigger, 'Electromagnetischer Multiplicator', Journal für Chemie und Physik (1821), 31, 35-41; J. C. Poggendorff, 'Physikalisch-chemische Untersuchungen zur nähern Kenntniss des Magnetismus der voltaischen Säule', Isis, oder Encyclopädische Zeitung (1821), 687-710; E. Gerland and F. Traumüller, Geschichte der physikalischen Experimentierkunst, Leipzig, 1899, 375-6; Clarke and Jacyna, op. cit. (7), 187-90.

9 L. Nobili, 'Descrizione di un nuovo galvanometro', Giornale de Fisica, Chimica, e Storia Naturale (1825), 8, 278-82, reprinted in Quarterly Journal of Literature, Science and Arts (1826), 20, 170-2; [G. W.] Muncke, 'Multiplicator. Galvanoskop, Galvanometer; Multiplicateur; Multiplicator', Johann Samuel Traugott Gehler's Physikalisches Wörterbuch (ed. H. W. Brandes, L. Gmelin, K. von Littrow, G. W. Muncke and C. H. Pfaff), 11 vols., Leipzig, 1825-45, vi.iii, 2476-509; du Bois-Reymond, op. cit. (6), i, 160-203; G. Wiedemann, Die Lehre vom Galvanismus und Elektromagnetismus, 2nd edn, 2 vols., Braunschweig, 1872-4, ii.i [Elektrodynamik, Elektromagnetismus und Diamagnetismus], 219-96; R. A. Chipman, 'The earliest electromagnetic instruments', United States: National Museum: Bulletin 240 (Contributions from the Museum of History and Technology, paper 38) Washington: Smithsonian Institution, 1964, 121-36; J. T. Stock and D. Vaughan, The Development of Instruments to Measure Electric Current, London, 1983; P. Brenni, 'La Galvanometer après Nobili', in Un siècle d'électricité dans le monde: 1880-1980. Actes du premier colloque international d'histoire de l'électricité, organisé par l'association pour l'histoire de l'électricité en France, Paris, 15-17 avril 1986, réunis et édités par Fabienne Cardot [Collection Histoire de l'électricité] Paris, 1986, 195-200, 205-22; C. Blondel, 'Entre l'électrophysiologie et l'électricité industrielle: le galvanomètre à cadre mobile', in Studies in the History of Scientific Instruments (ed. C. Blondel), London, 1989, 179-99.

10 The pioneer was Leopoldo Nobili, who was also the first to incorporate Ampère's astatic needles in Schweigger's multiplier. L. Nobili, 'Comparaison entre les deux galvanomètres les plus sensibles, la grenouille et le multiplicateur à deux aiguilles, suivie de quelques résultats nouveaux', Annales de chimie et de physique 
Du Bois-Reymond reported his galvanometer to be the most sensitive yet, the heat of a candle being enough to peg the needle. ${ }^{11}$ But though this remarkable instrument provided the most evident basis of his science, du Bois-Reymond's discoveries also rested on other, more modest, laboratory apparatus.

The problem with using a galvanometer to detect animal electricity was that the very contact between the electrodes and the tissue being investigated generated an electric current. This artefact had led to confusion at the turn of the century, and it was not until Alexander von Humboldt succeeded in demonstrating animal electricity in an experiment free of metal that the controversy ended. ${ }^{12}$ Still, even if the existence of animal electricity had been established beyond doubt, many physiologists felt ill at ease with the galvanometer. When it came to analysing the faint currents in muscles and nerves, they preferred an instrument that dispensed with electrodes entirely. For this they turned to the rheoscopic frog, a detector invented by Galvani and later modified by Matteucci. Despite its grandiose name, the rheoscopic frog could not have been simpler - it consisted of a frog's leg with the skin removed and a length of nerve left attached. The preparation was uncomplicated, convenient and inexpensive and, as long as it was not left sitting around for too long, quite reliable. The slightest charges touched by the nerve caused the leg to twitch unmistakably, no matter how transient or how faint the currents may have been. ${ }^{13}$

Considering the rheoscopic frog's advantages as a detector of animal electricity, one wonders why du Bois-Reymond bothered with a galvanometer at all. The answer is threefold. Foremost was the galvanometer's philosophical significance. Du BoisReymond felt he needed a physical device to demonstrate the identity of electricity in the organic and inorganic worlds. This principle of identity opened itself to challenge if animal preparations were used to display animal phenomena - in the end, one could always argue that the phenomena were specific to animals. Second, and in fairness to du Bois-Reymond, the galvanometer did have advantages over the rheoscopic frog as a detector of electricity. The galvanometer's needle responded to current, enabling it to show direction, intensity and variation in the electricity it measured. The rheoscopic frog, in contrast, responded only to charge. This made it ideal in certain laboratory situations - for example in registering very rapid electrical discharges and fluctuations - but limited its usefulness otherwise. A twitch is a plain sign: all or nothing. To

(1828), 38, 225-45; du Bois-Reymond, op. cit. (6), i, 103; W. D. Hackmann, 'Leopoldo Nobili and the beginnings of galvanometry', in Leopoldo Nobili e la cultura scientifica del suo tempo (ed. G. Tarozzi), Bologna, 1985, 203-33.

11 E. du Bois-Reymond, 'Vorläufiger Abriß einer Untersuchung über den sogenannten Froschstrom und über die elektromotorischen Fische', Annalen der Physik und Chemie (1843), 58, 1-30, 1 n. 1.

12 A. von Humboldt, Versuche über die gereizte Muskel- und Nervenfaser nebst Vermuthungen über den chemischen Process des Lebens in der Thier- und Pflanzenwelt, 2 vols., Posen, 1797, ii, 38-9; K. E. Rothschuh, 'Vom Spiritus animalis zum Nervenaktionsstrom', Ciba-Zeitschrift (1958), 8, 2959-79; K. E. Rothschuh, 'Alexander von Humboldt und die Physiologie seiner Zeit', Sudhoffs Archiv für Geschichte der Medizin und der Naturwissenschaften (1959), 43, 97-113; M. J. Trumpler, 'Questioning nature: experimental investigations of animal electricity in Germany, 1791-1810', Ph.D. dissertation, Yale University, 1992, UMI 9309006.

13 K. J. Fleckenstein, 'The rheoscopic frog and the study of animal electricity', Medical Instrumentation (1983), 17, 235-6. 
exhibit the properties as well as the presence of animal electricity, the experimenter needed a continuous signal. ${ }^{14}$ Finally, there were du Bois-Reymond's professional concerns. Matteucci's investigations with the rheoscopic frog were extensive. ${ }^{15}$ If du BoisReymond were to make his mark in animal electricity, it would have to be in some domain in which his predecessor had been less successful, namely in the design of devices.

Solving the problem of contact electricity proved to be du Bois-Reymond's first and best laboratory innovation. The trick was to find a buffer that conducted, and du BoisReymond hit on the idea of using wet filter paper. In this way, physical contact between the metal electrodes and the animal tissue could be avoided while electrical contact was maintained. Du Bois-Reymond arranged his apparatus as follows: rather than attaching the electrodes directly to the filter paper, he placed them in separate varnished glass vessels, each containing saturated solutions of salt and water. He then bent several layers of filter paper over the lips of the vessels, allowing the saline to soak through. After bringing the vessels near each other, he laid the preparation he wanted to investigate across the flat surface formed by the two bent pads of paper. Last, he removed a small bridge of paper connecting the pads to observe the action of the galvanometer needle.

This protocol seems simple, but du Bois-Reymond had to think hard about each step of the process, often wasting days before he realized, much less corrected, sources of error. ${ }^{16}$ His galvanometer's extreme sensitivity made it susceptible to the slightest electrical imbalances. Consequently, he devised an exhaustive procedure for ensuring absolute electrical equivalence in his electrodes. This involved washing the platinum plates in successive chemical baths, rinsing them with distilled water, and heating them until they glowed. To avoid contaminating the plates with static charge at any stage, he touched them only with glass rods. ${ }^{17}$ Equally painstaking were the efforts he made to maintain his galvanometer's neutrality. He fashioned guards to protect his equipment

14 Du Bois-Reymond, op. cit. (6), i, 251-9. Du Bois-Reymond wrote in defence of the galvanometer, 'You must remember this: a twitch is just a twitch, a cry is just a cry. The fundamental laws apply - as frog legs die'.

15 C. Matteucci, 'Mémoire sur l'électricité animale', Annales de chimie et de physique (10 septembre 1834), 56, 439-43; idem, 'Recherches sur l'électricité animale', Comptes rendus (9 octobre 1837), 5, 520-1; idem, 'Sur le courant électrique ou propre de la grenouille; second mémoire sur l'électricité animale, faisant suite à celui sur la torpille', Annales de chimie et de physique (1838), 68, 93-106; idem, Essai sur les phénomènes électriques des animaux, Paris, 1840; idem, 'Deuxième mémoire sur le courant électrique propre de la grenouille et sur celui des animaux à sang chaud', Annales de chimie et de physique (1842), 6, 301-9; idem [Report on muscle contraction current read by J. M. Dumas on 24 October 1842], Comptes rendus (24 octobre 1842), 15, 797-8; idem, 'Sur un phénomène physiologique produit par les muscles en contraction', Annales de chimie et de physique (1842), 6, 339-42; idem, Traité des phénomènes électro-physiologique des animaux (Paris, 1844); idem, 'Expériences sur les phénomènes de la contraction induite (lettre à M. Dumas)', Annales de chimie et de physique (September 1845), 15, 64-70; idem, 'Electro-physiological researches. First memoir. The muscular current', Philosophical Transactions (5 June 1845), Part I, 283-95; idem, 'Electro-physiological researches. - Second memoir. On the proper current of the frog', Philosophical Transactions (19 June 1845), Part I, 297-301; idem, 'Electro-physiological researches. - Third memoir. On induced contractions', Philosophical Transactions (20 November 1845), Part II, 303-17; idem, Lectures on the Physical Phenomena of Living Beings (tr. J. Pereira), London, 1847.

16 Du Bois-Reymond, op. cit. (6), i, 203, 227.

17 Du Bois-Reymond, op. cit. (6), i, 206. 
from splashes, clamps to hold his materials in place and chambers to keep his preparations isolated. ${ }^{18}$

Similarly, du Bois-Reymond learned to exercise equal care with his experimental material. He chose saline as his electrolyte after testing several more caustic solutions. ${ }^{19}$ He covered all but a portion of his filter paper with squares of pig bladder soaked in egg white after discovering that prolonged contact with salt could damage his preparations. ${ }^{20}$ He varied ways to store his frogs after yearly winter losses. In time, he took pride in his laboratory skill, but it was a pride grown of repeated, bitter, trials. ${ }^{21}$

Success arrived in May of 1842. As if to mirror the end of his struggles, the most painfully beautiful spring he could remember bloomed into summer. The light in Berlin that season is fine and bright, and he experimented as long as it lasted. His work was a joy. Every day held the prospect of something new, and indeed he went from discovery to discovery. ${ }^{22}$ His pace continued into the autumn. Realizing that he was nearing the end of his medical studies and that he had accomplished far more in animal electricity than his degree required, he asked Müller if he might substitute another topic for his report and continue his researches as the basis of a treatise. His advisor agreed. Matteucci had sent Müller a letter detailing his latest experiments, but now that Müller understood how far his student had come on his own, he recognized that there was no need to remain impartial. Du Bois-Reymond's discoveries were superior, and it was imperative that he should publish immediately to establish priority. Müller thought it might raise suspicion if his journal were involved, so he arranged in November to have du Bois-Reymond's work published in Poggendorff's Annalen der Physik. The article came out in January 1843, and for the benefit of the 'damned French' du Bois-Reymond sent a longer translation to Paris. ${ }^{23}$

The 'Preliminary abstract of an investigation into the so-called frog current and the electromotive fishes' compressed the findings of the six months between May and November 1842 into five notable discoveries. The first, that of permanent electrical currents in muscular tissue, borrowed directly from Matteucci. While admitting this debt without reservation, du Bois-Reymond also claimed that his competitor had forfeited credit for the discovery after hopelessly misunderstanding it. According to du Bois-Reymond, Matteucci's confusion arose from a putative difference in the behaviour of organisms and tissues in the laboratory. It had been long known that living frogs produced weak currents. What was not clear was whether this property was specific to

18 Du Bois-Reymond, op. cit. (6), i, 217-27.

19 Du Bois-Reymond, op. cit. (6), i, 217.

20 Du Bois-Reymond, op. cit. (6), i, 222-3.

21 Du Bois-Reymond, op. cit. (6), i, 227-33.

22 Compare his laboratory notebooks, $1842-12$. 1843, Staatsbibliothek Preußischer Kulturbesitz zu Berlin, Haus 2, Handschriftenabteilung, Nachlaß Emil du Bois-Reymond (subsequently dB-R papers), K. 10, Nr. 4.

23 Entlassungsattest aus dem einjährigen, freiwilligen Chirurgendienst bei der Kgl. Cadetten-Anstalt in Berlin, Berlin, 30.9.1842, dB-R papers, K. 1, M. 1, Bl. 12-13; Emil du Bois-Reymond to Eduard Hallmann, März 1843, op. cit. (1), 110-14, 110; Johannes Müller to Emil du Bois-Reymond, 14 November 1842, Staatsbibliothek Preußischer Kulturbesitz zu Berlin, Handschriftenabteilung, Haus 2, Sammlung Darmstädter (subsequently SD), 3k 1826 (2) Bl. 10. 
the species or just an artefact of various degrees of electrical activity in the muscles. Matteucci thought the former. Between 1834 and 1838 he detected currents in a preparation he called the 'frog pile', effectively a battery of dissected thigh muscles. He also detected currents between the head and the foot of the whole frog. But when he directed the current of his frog pile through individual nerves and muscles, his galvanometer showed nothing. He therefore assumed that currents derived from preparations and currents derived from live animals were distinct. ${ }^{24}$

Du Bois-Reymond thought this preposterous. He had always discounted the notion of currents specific to life, but beyond this it seemed ridiculous that the frog be elected from all species in the animal kingdom to possess unique and mysterious electrical powers. ${ }^{25} \mathrm{He}$ decided that the mistake lay in Matteucci's method. Sure enough, he discovered the source of error. Like du Bois-Reymond, Matteucci placed his platinum electrodes in saline, but unlike him, he used a weak solution soaked into a mass of cotton wool. As a result, he lost the power to regulate the depth and composition of the fluid affecting his experimental preparation, and consequently any control over currents arising from variations in his set-up. ${ }^{26}$ Matteucci's system sufficed for the grossest measurements, such as for that of the live subject, but if currents were to be demonstrated in isolated muscles, more sensitivity was needed. Du Bois-Reymond found that each portion of the frog produced electricity, and therefore concluded that the 'frog current' was a chimera. What Matteucci had measured was just a summation of separate, unequal muscular currents through the body of the entire animal. ${ }^{27}$

Du Bois-Reymond's technique of analysing the whole frog in terms of component currents led him to his second discovery. This was the law of muscular current, an achievement that since has fallen into oblivion. As before, du Bois-Reymond extended the work of his rival. Matteucci described the muscular current as directed from the centre to the surface of the muscle, much like a Leyden jar. ${ }^{28}$ Matteucci attributed the electricity to 'heterogeneity', in this case to the difference between arterial blood within and muscular fibre without. ${ }^{29}$ This was not an unreasonable assertion. Contact between chemically different substances produced currents elsewhere - why not in the body? $\mathrm{Du}$ Bois-Reymond soon found, however, that this theory failed to explain his own

24 C. Matteucci, 'Mémoire sur l'électricité animale', op. cit. (15), 442-3; idem, 'Sur le courant électrique ou propre de la grenouille', op. cit. (15), 104-5; idem, 'Deuxième mémoire sur le courant électrique propre de la grenouille', op. cit. (15). On Matteucci, see G. Moruzzi, 'The electrophysiological work of Carl Matteucci', in Per la storia della neurologia italiana=Essays on the History of Italian Neurology: Proceedings of the International Symposium on the History of Neurology, Varenna, 30. VIII./1. IX. 1961 (ed. L. Belloni), Milan, 1963, 139-47; idem, 'L'opera elletrofisiologica di Carlo Matteucci', Physis (1964), 6, 101-40; idem, Il contributo di Carlo Mattencci alla creazione del modello fisico del nervo, Ferrara, 1973; idem, 'Carlo Matteucci', DSB (1974), 9, 176-7; Clark and Jacyna, op. cit. (7), 198-211.

25 Du Bois-Reymond, op. cit. (6), i, 541; idem, 'Elektrophysiologie', Fortschritte der Physik im Jahre 1848. Dargestellt von der Physikalischen Gesellschaft zu Berlin (1852), 4, 301-29, 320-6.

26 Du Bois-Reymond, op. cit. (6), i, 119-20.

27 Du Bois-Reymond, op. cit. (11), 31; idem, op. cit. (6), i, 518-19.

28 C. Mattuecci [Report on muscle contraction current read by J. M. Dumas on 24 October 1842], op. cit. (15); idem, Traité, op. cit. (15), 52.

29 C. Matteucci, 'Electro-physiological researches.-First memoir. The muscular current', op. cit. (15), 294. 


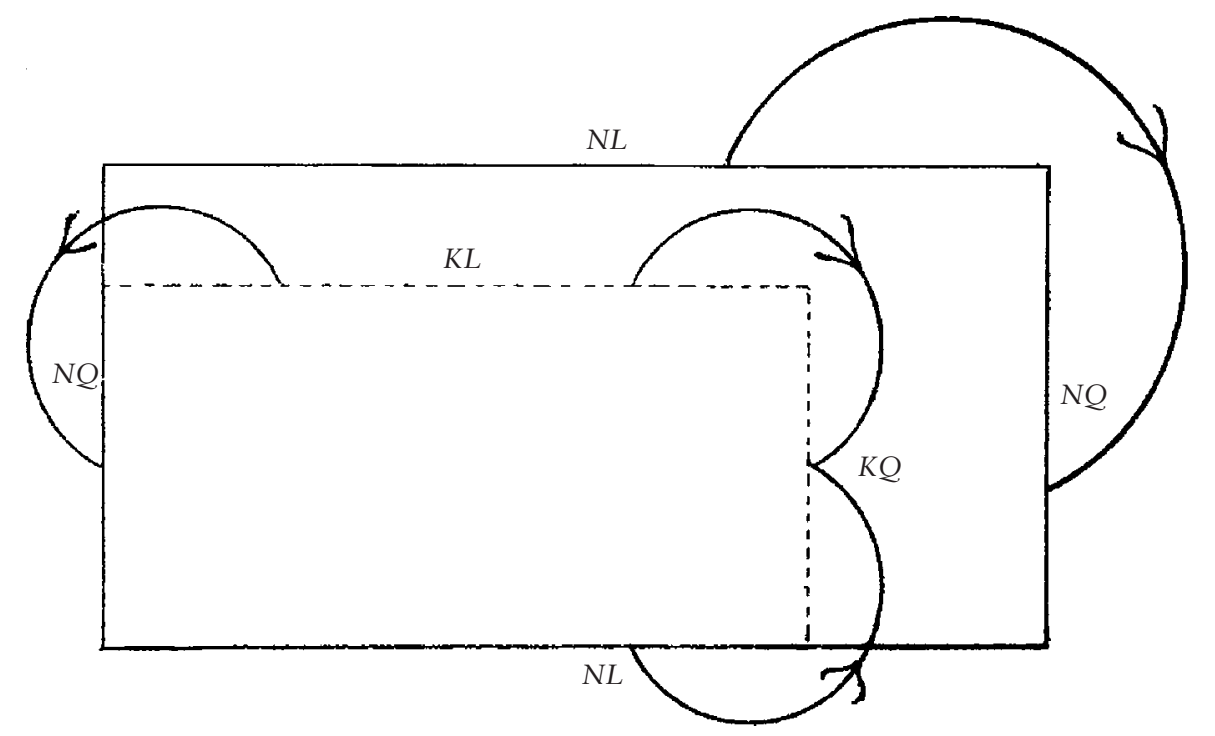

Figure 3. Law of muscle current. Direction of flow is from long-section to cross-section. The smaller dotted rectangle indicates that the law holds for muscle sections as well.

observations. Pieces of frog tissue moistened with chemical solutions exhibited no sign of electrical activity, and litmus paper placed on the muscle surface failed to change colour.$^{30}$ Moreover, Matteucci's geometry was off. Charge flowed not from interior to exterior, but from long-section to cross-section, long-section referring to surfaces parallel to the grain and cross-section to surfaces perpendicular (Figure 3). ${ }^{31}$

The law of the muscle current must have surprised du Bois-Reymond, because he tested it repeatedly. He tested it in various orientations of muscle and apparatus; he tested it in various muscles; he tested it in various fragments of tissue down to a single isolated fibre; he even tested it in various animals, including 'rabbit, guinea-pig, mouse, pigeon, tortoise, lizard, water frog, grass frog, leaf frog, salamander, tench and crab' ${ }^{32}$ Each time he found the law confirmed. As long as the conducting cushions spanned long-section and cross-section, the galvanometer needle deflected. But for all its universality, the law of muscle current remained conservative. It ultimately expressed a relationship in space - flow between surfaces - and in this respect it belonged as much to anatomy as to physiology. Du Bois-Reymond admitted himself that the key to his discovery came to him only after long study of eighteenth-century muscle diagrams. ${ }^{33}$

30 Du Bois-Reymond, op. cit. (6), i, 116; 121. Matteucci later abandoned the electrochemical theory of frog current.

31 Du Bois-Reymond, op. cit. (11), 11-15; du Bois-Reymond, op. cit. (6), i, 498-518.

32 E. du Bois-Reymond, On Animal Electricity: Being an Abstract of the Discoveries of Emil du BoisReymond (ed. H. Bence Jones), London, 1852, 170.

33 G. Alfonso Borelli, De Motu Animalium. Editio nova neapolitana, a plurimis mendis repurgata, ac dissertationibus physico-mechanicis de motu musculorum, et de efferverscentia, et fermentatione, ... Joh. Bernoulli aucta et ornata, Neapoli, 1734, plate 1; du Bois-Reymond, op. cit. (6), i, 538-9. 


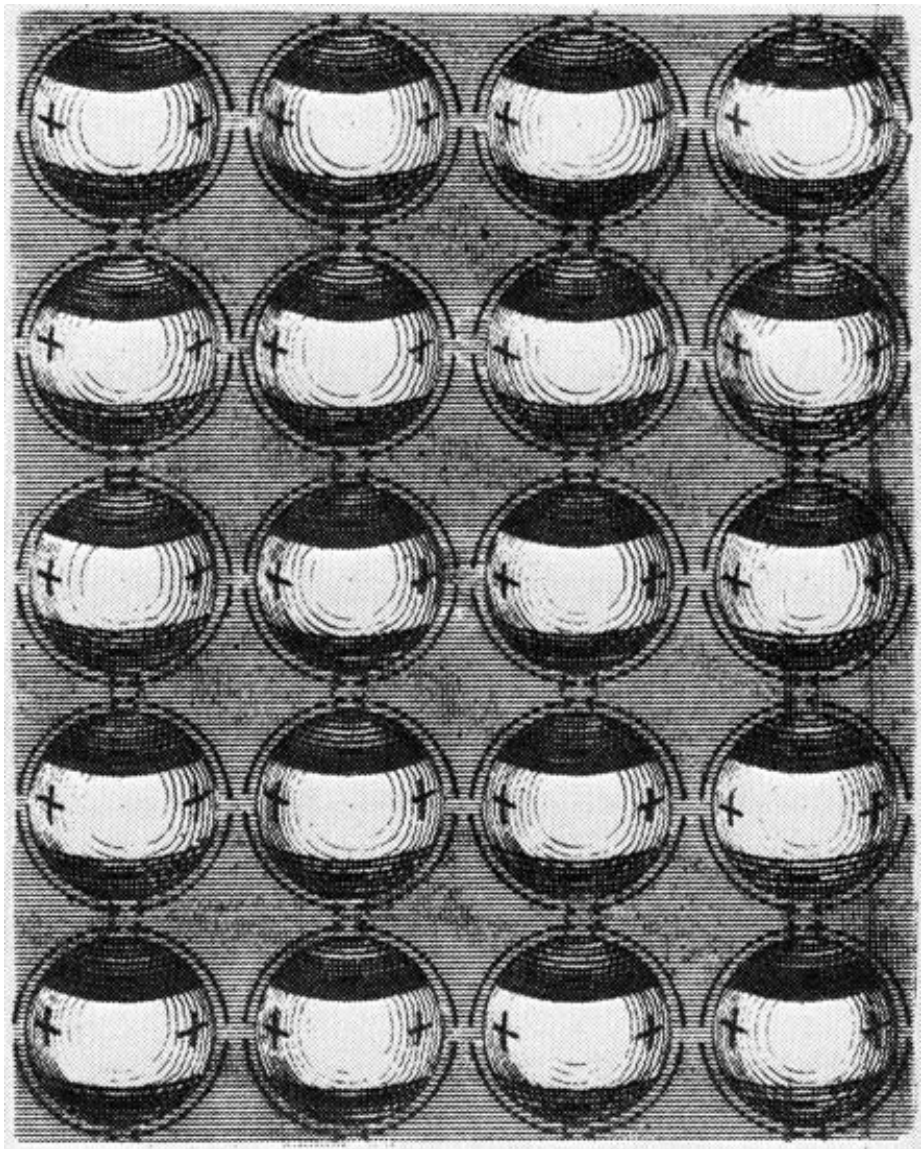

Figure 4. Molecular model of muscle tissue. The peripolar distribution of charge accounts for the law of muscle current, even in the tiniest sections.

His theory of the current's origin also borrowed from morphology. Du BoisReymond pictured each muscle as a cylindrical battery, the poles separating into a positive sheath and a negative interior, an arrangement that accounted for the current between muscle surface and muscle ends. ${ }^{34}$ But since the law of muscle current held for even the smallest of fibres, he modified the model by adding multiple elements, replacing the concentric cylinders with peripolar spheres (Figure 4). ${ }^{35}$ This change allowed him to section his model without altering its properties, just as sectioning the

34 Du Bois-Reymond, op. cit. (11), 25. Du Bois-Reymond later built a physical model of this battery to test his theory. Idem, op. cit. (6), i, 553-684, 658, Tafel VI, Fig. 71. He was not happy with the results: 'Ich brauche den Leser wohl nicht erst zu versichern, daß Niemand tiefer als ich selber empfinden kann, wie viel diese Auseinandersetzungen an Schärfe und Klarheit im Einzelnen zu wünschen übrig lassen'. Du BoisReymond, op. cit. (6), i, 655.

35 Du Bois-Reymond, op. cit. (11), §§43-4. 
actual muscle left the behaviour of its electric law invariant. In this way he linked the geometry of electromotive function to the geometry of anatomical observation.

Du Bois-Reymond's model supplied an analogy, but without description of how peripolar molecules became electromotive the theory remained incomplete. Here he turned to the chemistry of combustion. Claude Servais Mathias Pouillet recently had shown that when carbon burned, the carbon dioxide produced became positive compared to the fuel. ${ }^{36}$ It was known that respiration converted oxygen to carbon dioxide might this organic reaction be the motor of animal electricity? Du Bois-Reymond suggested that it would explain the phenomena: the muscle fibres respired best at their surfaces, and the heterogeneity between surface and end corresponded to the current observed. The hypothesis also clarified why bare muscles produced more electricity than those covered with skin: flaying the muscle exposed more surface to oxidation, increasing the rate of respiration and thereby the current generated. ${ }^{37}$

Du Bois-Reymond admitted his theory's limitations. If respiration produced animal electricity, currents should arise in all fibrous tissue, not just in muscles and nerves. Pursuing this implication, he attempted to detect electrical activity in bones. Here he registered a difference in potential between the surface and the marrow, but he was not satisfied with his results. Additional attempts to link oxygen concentration to current intensity proved inconclusive, and he gave up trying to identify respiration as the engine of electromotive power. ${ }^{38}$

Nevertheless, he justified biological mechanism as best he could, and for du BoisReymond that meant employing arguments of symmetry. The law of muscular current, for example, was based on infinite divisibility, where each part of the muscle reproduced the properties of the whole. The peripolar molecule was, in effect, the terminus of a train of division begun with the scalpel and ended in the mind - the muscle reduced to its simplest logic. Since function followed form, the organic was cognate to the inorganic. All objects, whether muscles or magnets, displayed properties that ultimately derived from their structure. ${ }^{39}$

\section{The negative variation}

Du Bois-Reymond's third and fourth discoveries demonstrated the nervous current and its law, work that exactly parallelled his first two findings in muscles. Where he finally addressed the problem of organic action was in his fifth discovery, that of the decrease - or 'negative variation' - in animal electricity during tetanus. This find was his most original, marking one of the salient events in modern physiology, the proof that electricity acts as a biological signal. More important, it established beyond question the power of his method.

36 C. Pouillet, 'Mémoire sur l'électricité des fluides élastiques, et sur une des causes de l'électricité de l'atmosphère', Annales de chimie et de physique (30 mai 1825), 35, 401-20. Pouillet was expert in the use of the galvanometer. R. Taton, 'Claude-Servais-Mathias Pouillet', DSB (1975), 11, 110-11.

37 Du Bois-Reymond, op. cit. (11), 52-60.

38 Du Bois-Reymond, op. cit. (11), 63.

39 Du Bois-Reymond, op. cit. (6), i, 678-83. 
Like his other contributions, this one rested on previous work. Tetanization was a procedure common to muscle physiologists, and it seemed to have attracted almost prurient interest. One could send a muscle into tetanic contraction by any number of injuries: blows, burns, irritation, poison and, the favourite of physicists, electric shock. ${ }^{40}$ Here, as elsewhere, Matteucci turned up as the first to investigate the phenomenon with a galvanometer, but his experiments displayed more originality than thoroughness. Matteucci began by observing that tetanus caused a decrease in the strength of the muscular current, then changed his mind to an increase, and finally decided on no effect at all. ${ }^{41}$ Despite this confusion, du Bois-Reymond recognized the implications of Matteucci's research and followed it up with his own.

The main limitation of the galvanometer was its lethargy of response: the more sensitive the needle, the longer it took to oscillate. This delay did not matter in measuring currents that lasted - all the experimenter had to do was wait for the needle to rest and see where it pointed. Measuring transient currents, however, presented a problem. Unless the signals were very strong they failed to budge the needle, and when they did the movement was often so slight as to leave the experimenter in doubt. The trick was to find some way to multiply the effect of individual electrical impulses. Tetanus accomplished this perfectly. As du Bois-Reymond proved with the rheoscopic frog, the tetanic state of the muscle actually consisted of a succession of short contractions. ${ }^{42}$ Each of these gave rise to a weak shock, but since they followed one another rapidly, the galvanometer summed their effects. In this way tetanus allowed the experimenter to match the prolonged action of instruments to the transient action of tissues. Long before amplifiers and oscilloscopes, tetanus magnified physiological time just as microscopes magnified physiological space. ${ }^{43}$

$\mathrm{Du}$ Bois-Reymond preferred to tetanize his preparations by electrical means. His choice did not show anything remarkable, considering the number of instruments available to him. ${ }^{44}$ There were, among others, Grove's element, Poggendorff's inverter, Saxton's machine and Neef's magneto-electromotor - all devices engineered to generate electric shocks. Du Bois-Reymond favoured the last. ${ }^{45}$ The electromotor produced

40 Du Bois-Reymond, op. cit. (11), 35; idem, op. cit. (6), ii, 32-49.

41 Du Bois-Reymond, op. cit. (6), ii, 11-30.

42 Du Bois-Reymond, op. cit. (6), ii, 87-92.

43 H. E. Hoff and L. A. Geddes, 'The rheotome and its prehistory: a study in the historical interrelation of electrophysiology and electromechanics', Bulletin of the History of Medicine and Its Allied Sciences (1957), 31, 212-34, 327-47; K. E. Rothschuh, 'Die Bedeutung apparativer Hilfsmittel für die Entwicklung der biologischen Wissenschaften im 19. Jahrhundert', in Naturwissenschaft, Technik und Wirtschaft im 19. Jahrhundert. 8. Gespräche der Georg-Agricola-Gesellschaft zur Förderung der Geschichte der Naturwissenschaft und der Technik, 2 vols., Göttingen, 1976, ii, 161-85.

44 Du Bois-Reymond, op. cit. (6), ii, 35-45; W. D. Hackmann, 'The induction coil in medicine and physics, 1835-77', in Studies in the History of Scientific Instruments (ed. Christine Blondel, Françoise Parot, Anthony Turner and Mari Williams), London, 1989, 235-50.

45 Emil du Bois-Reymond to Carl Ludwig, 22 April 1848, Two Great Scientists of the Nineteenth Century: Correspondence of Emil du Bois-Reymond and Carl Ludwig (tr. S. Lichtner-Ayèd, ed. with a foreword by P. F. Cranefield), Baltimore, London, 1982, 8-14, 14. Helmholtz agreed. R. L. Kremer, 'The thermodynamics of life and experimental physiology, 1770-1880', Ph.D. dissertation, Harvard University, 1984, 300, UMI 8503544 . 
alternating current, and this held three main advantages: it permitted weaker, less damaging shocks to induce tetanus; it lowered the rate of electrolytic decomposition in the preparations; and it kept the galvanometer electrodes from becoming polarized. ${ }^{46}$

Du Bois-Reymond's basic experiment for observing the negative variation went as follows. As a control, he first laid the frog gastrocnemius and attached nerve across the conducting cushions so that the nerve rested on the thigh muscle. When he closed the circuit, the galvanometer needle flew against the checks, swung back and forth, and gradually settled at a deflection of between ten and twenty degrees, indicating the presence of a normal muscle current. Next, he lifted the nerve off the muscle and spread the free end over the two platinum leads from the magneto-electromotor. Taking hold of the generator handle, he cranked the wheel. The muscle seized with tetanus. Simultaneously, the galvanometer needle reversed its position, passing straight through the zero point of the dial into the negative quadrant, where it oscillated around a point of equilibrium (Figure 5). ${ }^{47}$

Du Bois-Reymond considered the negative variation indubitable. He stated his case plainly:

This is not some trace observance that has to be carefully discerned amidst ambiguous conditions and cases of failure. No, this is about a needle moving forty to seventy degrees, about an experiment so striking, simple and secure in its success that, as long as I have apparatus and frogs ready, I volunteer to repeat it at any time, at any place, as often as desired, without it once failing. ${ }^{48}$

And apparently he did exactly that, demonstrating the effect to everyone who would watch: Johannes Müller, Heinrich Wilhelm Dove, Gustav Magnus, Johann Christian Poggendorff, Peter Riess, Eilhard Mitscherlitsch, Christian Gottfried Ehrenberg and Heinrich and Gustav Rose. Those who attended his performances did not forget them, especially if they viewed his version with the live animal. Here du Bois-Reymond fixed a frog in a clamp, sliced open its back and tetanized the spinal cord directly. The demonstration proved that his discovery obtained not just for his dissected preparations but also for the whole frog. This knowledge came at a terrible cost. Du Bois-Reymond reminded his readers 'how unbearably shocks hurt in even the slightest wound. The frogs in my experiments must have endured monstrous pain, as their behaviour, a

46 Du Bois-Reymond, op. cit. (6), ii, 45-50. Du Bois-Reymond developed Neef's motor into his famous sliding carriage apparatus. See his description in 'Electrophysiologie', Fortschritte der Physik im Jahre 1846. Dargestellt von der Physikalischen Gesellschaft zu Berlin (1848), 2, 436-75, 462; Emil du Bois-Reymond to Carl Ludwig, 22 April 1848, op. cit. (45), 8-14.

47 Laboratory notebooks, 1841-2, dB-R papers, K. 10, Nr. 1, Bl. 11v; du Bois-Reymond, op. cit. (6), ii, $50-1$.

48 Es handelt sich hier nicht um spurweise Wabrnehmungen, die dann und wann unter zweideutigen Umständen, durch eben so viel ungünstige Fälle aufgewogen, sorgenvoll erspäht werden müssen; nein, sondern um Nadelbewegungen von 40-70, um einen Versuch, so schlagend, einfach, sicher und beständig in seinem Erfolge, daß ich ihn, wenn meine Vorrichtung im Stande und Frösche bei der Hand sind, an jedem Orte, zu jeder Stunde, beliebig viele Male hintereinander, ohne daß auch nur ein einziges versagte, zu wiederholen mich anheischig mache.

Du Bois-Reymond, op. cit. (6), ii, 26. 


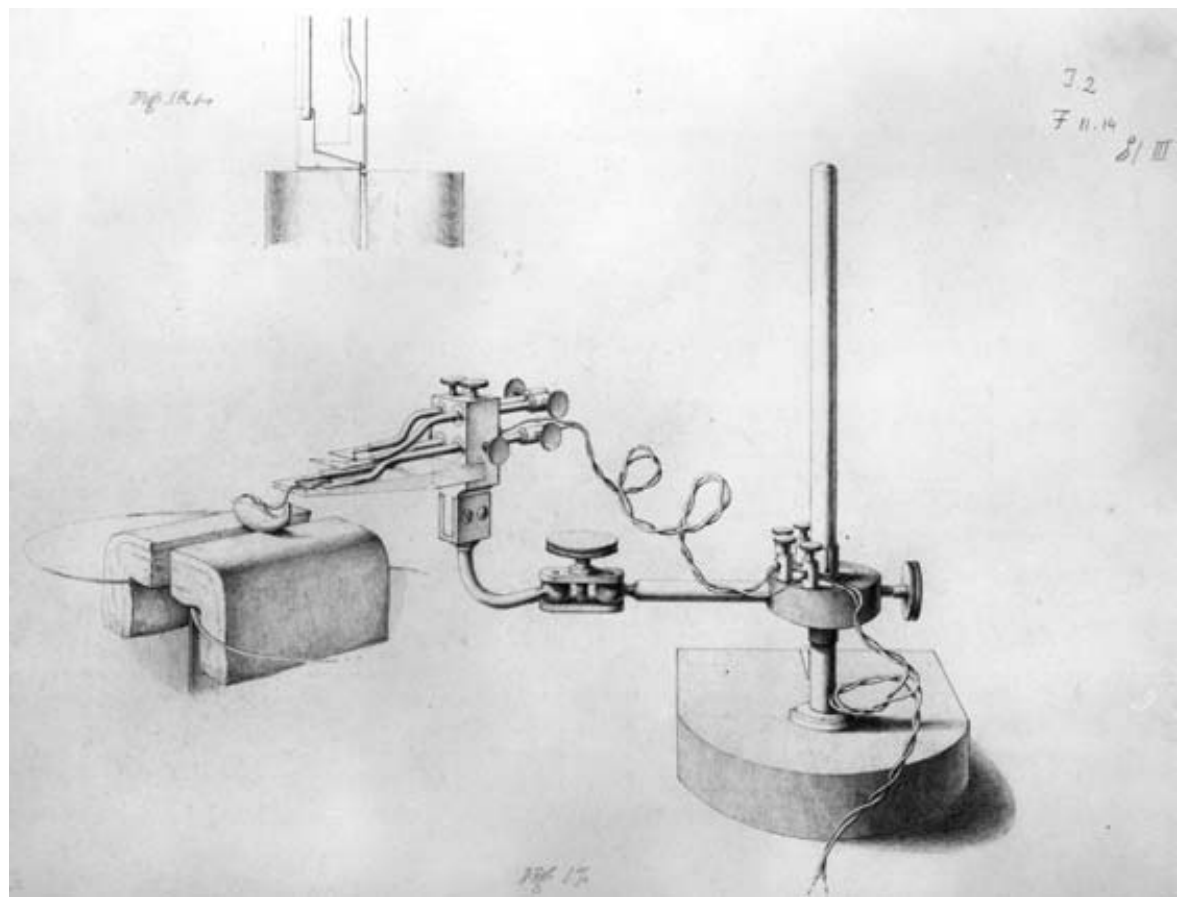

Figure 5. Laboratory apparatus for observing negative variation. Top: metal electrodes for stimulating the nerve. Bottom: arrangement for detection of negative variation in the muscular current. The frog gastrocnemius rests across two conducting pads bent over the edges of the saline vessels. (The rest of the circuit extending to the galvanometer is not shown.) Metal electrodes, held in place by an adjustable stand, stimulate the nerve. The twisted wires trail off to some source of electricity, most likely a magneto-electromotor.

horrible writhing and cooing, bore only too vivid witness'. ${ }^{49}$ The scientist surely empathized with his subjects; in the tradition of Johann Wilhelm Ritter and Johannes Müller, he subjected himself to an agonizing regimen of electrocution, but in every case he failed to detect the negative variation in his own body. ${ }^{\mathbf{5 0}}$

\section{The 'Super': investigations in animal electricity (1848-9)}

During the next five years du Bois-Reymond extended his programme of research. His 'Preliminary abstract' had ended with an account of the negative variation, or signal, in the currents of muscles; it remained for him to prove the existence of a similar

49 Man erinnert sich, wie unerträglich der elektrische Strom dauernd auch in der geringsten Verletzung schmerzt; die Qualen, denen solchergestalt die Frösche in meinen Versuchen unterlagen, mußten ungeheuer sein, und ihr Benehmen dabei, ein gräßliches Winden und Girren, legte davon ein nur zu sprechendes Zeugniß ab.

Du Bois-Reymond, op. cit. (6), i, 456. The violence of the tetanus often forced the frog's entrails out of the incision. Du Bois-Reymond, op. cit. (6), ii, 56-7.

50 Du Bois-Reymond, op. cit. (11), 49. 

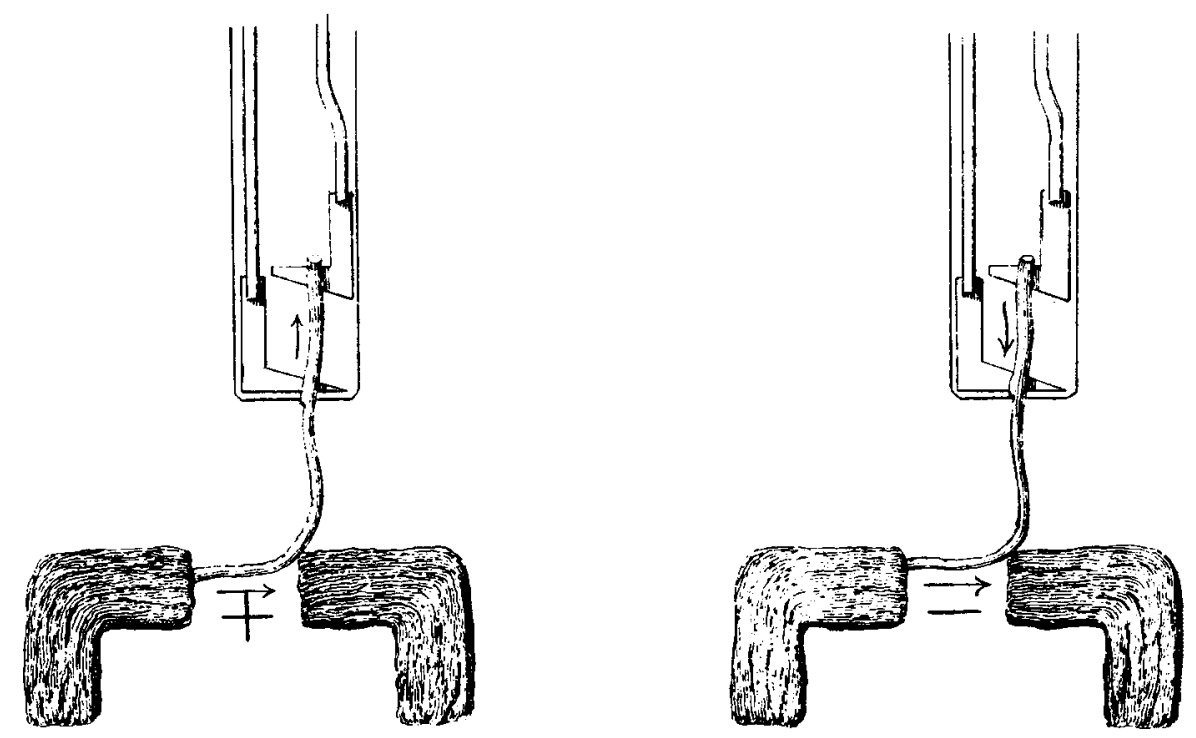

Figure 6. Electrotonus. Arrows indicate the directions of stimulating (top) and nervous (bottom) currents. On the left, electrotonus has augmented the current derived from the nerve; on the right, it has diminished it.

variation, or signal, in the currents of nerves. Only then could he claim, if he 'had not completely deluded [himself] ... to have succeeded in restoring to life, in full reality, that hundred-year-old dream of the physicist and physiologist: the identity of the nervous principle with electricity'. ${ }^{51}$ The story of this success is the high point of the laboratory experiments recounted in the two volumes of his Investigations in Animal Electricity.

Du Bois-Reymond's plan was direct: he would stimulate the nerve and then observe the resulting diminution in current. He immediately ran into difficulties. His preparation reacted oddly to electricity. It allowed a weak current to pass through, but not in the manner of a poor conductor. Instead it appeared to enter a state of polarization, the strength of which depended on the duration of electricity applied. This 'electrotonic' state, as du Bois-Reymond called it, generated its own unique current, one distinct from both the extrinsic current of stimulation and the intrinsic current of the nerve (Figure 6). ${ }^{52}$

Du Bois-Reymond developed a theory of this 'electrotonus' by analogy to Michael Faraday's theory of induction..$^{53}$ According to Faraday, electric currents subjected

51 'Es ist mir, wenn mich nicht alles täuscht, gelungen, jenen hundertjährigen Traum der Physiker und Physiologien von der Einerleiheit des Nervenwesens und der Elektricität, wenn auch in etwas abgeänderter Gestalt, zu lebensvoller Wirklichkeit zu erwecken'. Du Bois-Reymond, op. cit. (6), i, p. xv.

52 Du Bois-Reymond, op. cit. (6), ii.i, 289-389.

53 Du Bois-Reymond, op. cit. (6), i, 302; M. Faraday, Experimental Researches in Electricity, 3 vols., London, 1839-55, i, 16-22. Du Bois-Reymond sent two copies of his book to Faraday, requesting him to pass one on to the Royal Society. Emil du Bois-Reymond to Michael Faraday, October 1849, SD F1 e 1831 (2) 
A
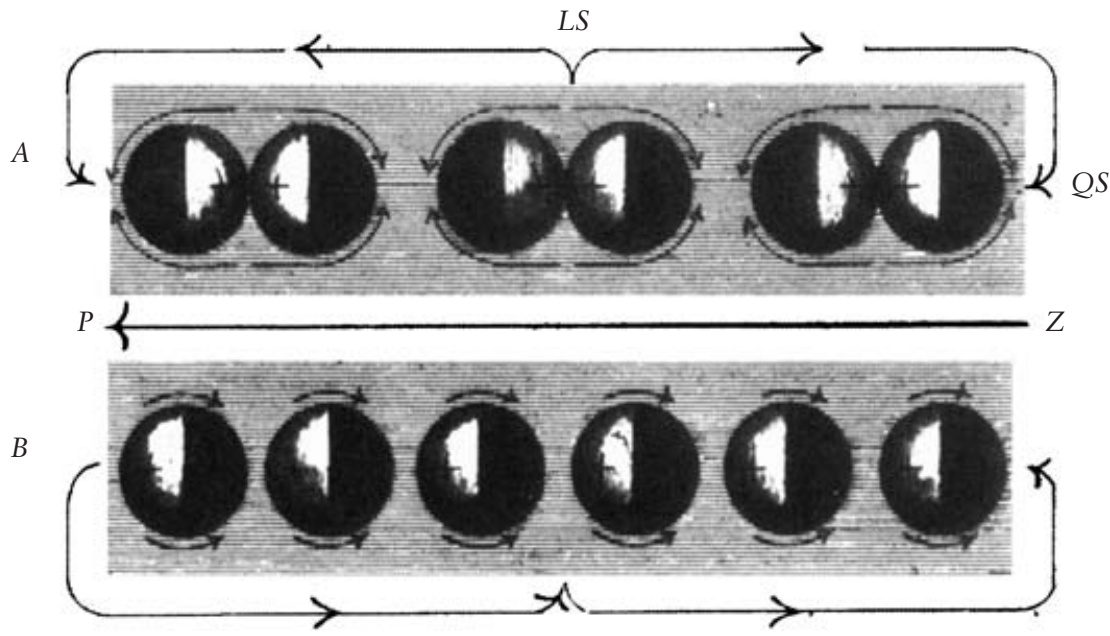

Figure 7. Molecular model of electrotonus. The distribution of charge in nerve molecules changes from peripolar $(A)$ to dipolar $(B)$ when direct current is run through the nerve.

molecules in and near conductors to a peculiar state of tension. Du Bois-Reymond argued that this tension could also affect living tissue. Somehow - and here he was at a loss to explain how, other than a vague appeal to the phenomenon of electrolysis - the tension forced organic molecules within the nerve to change from peripolar to dipolar distributions of charge. ${ }^{54}$ The net result was 'pile-like polarization' - in other words the molecules lined up in a biological battery (Figure 7). This array of sequentially alternating charges gave rise to the strange current that he had seen. ${ }^{\mathbf{5 5}}$

The discovery of electrotonus confronted du Bois-Reymond with an impasse. His galvanometer could register currents from various sources, but it could not differentiate between them. To prove his hypothesis, he needed to find a way of exciting the nerve without inducing the electrotonic state. Once again, Neef's machine provided the answer. The magneto-electromotor kept polarization to a minimum with rapid shocks and alternating phases. Furthermore, since the negative variation, unlike electrotonus, responded to change and not duration in current, the machine could work efficiently at very low voltages. This was a boon to the experimenter, since prolonged shocks tended

Bl. 7. Cf. I. R. Morus, 'Marketing the machine: the construction of electrotherapeutics as viable medicine in early Victorian England', Medical History (1992), 36, 34-52.

54 H. Bence Jones (ed.), On Animal Electricity: Being an Abstract of the Discoveries of Emil du BoisReymond, London, 1852, 185.

$55 \mathrm{Du}$ Bois-Reymond, op. cit. (6), ii.i, 320-8. A note on the early history of animal electricity - the electrotonic state allowed du Bois-Reymond to prove Johann Wilhelm Ritter and Paul Erman's conjecture on the theory of galvanic contraction:

the action which produces contraction, and which arises at the moment of closing the circuit, is produced by the transitions of the nerve into another state; and that the action of the current consisted in putting the nerve into this new condition, in which it remained as long as the circuit was closed, so that the contraction on breaking the circuit was caused by the return of the nerve to its original state.

H. Bence Jones, op. cit. (54), 184. Cf. Du Bois-Reymond, op. cit. (6), i, 303-409; M. Trumpler, op. cit. (12). 


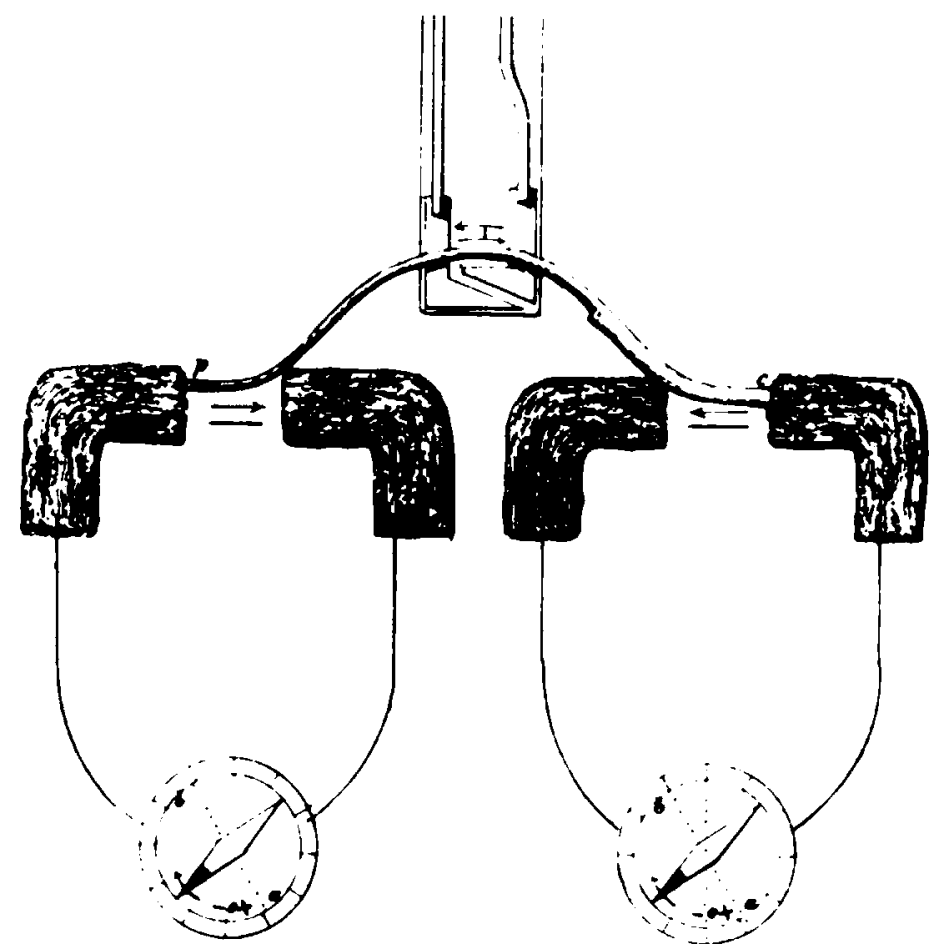

Figure 8. Experiment with two galvanometers demonstrating negative variation in the nerve. Metal electrodes stimulate the middle section of the preparation. Arrows indicate current directions. In the figure, both galvanometer needles have deflected away from position $a$, indicating the response of the nerve to tetanization.

to damage the preparations. ${ }^{56}$ The machine also possessed the advantages of portability, reliability and regularity, the gradation of the shocks being controlled by means of du Bois-Reymond's sled inductor. ${ }^{57}$

With this set-up du Bois-Reymond succeeded in detecting the negative variation in nerves subjected to electrical tetanus. Though he needed only one galvanometer to observe the effect, his most elegant demonstration employed two: one placed at each end of the nerve, with the pair of stimulating electrodes placed at the midpoint (Figure 8$).{ }^{58}$ When he applied no current at all, the nerve simply obeyed his law. Electricity flowed from long-section to cross-section, and the needles of the two galvanometers registered deflections in the same direction. When he applied direct current, the nerve entered the electrotonic state. The bias of the ensuing current destroyed the nerve's electrical symmetry and, in consequence, the galvanometer needles swung apart. Finally, when he applied alternating current, the negative variation became

56 Du Bois-Reymond, op. cit. (6), ii.i, 390-423.

57 Du Bois-Reymond, 'Elektrophysiologie', Fortschritte der Physik (1846), 2, 436-75, 461-2.

58 Du Bois-Reymond, op. cit. (6), ii.i, 300-3. 
visible. The needles again swung together, but not as far as in the first case, indicating a decrease in nervous current triggered by the external circuit of tetanization.

$\mathrm{Du}$ Bois-Reymond took great pains to prove this last point. In tetanizing the nerve electrically, he knew that he had left himself open to the criticism that his results were merely an artefact of the stimulating current. How could the experimenter be sure, a sceptic might ask, that the swing of the galvanometer needle represented a condition located in the nerve and not in the electric machine? Du Bois-Reymond anticipated this objection and countered with the following arguments. Since the negative variation indicated a nervous signal, it should vary with the orientation of the nerve, not the stimulating current, as was indeed the case. Moreover, the effect increased after a few passes of tetanization, which would be inexplicable if it were due to some form of excitatory interference or metabolic process. Finally, the negative variation depended on the specific excitability of the nerve. If the frog's fatigue, health and season of capture influenced the strength of the response, and if ligating or severing the nerve blocked it altogether, the effect could not possibly derive from an external source. ${ }^{\mathbf{5 9}}$

Even so, du Bois-Reymond knew that the best way to eradicate doubt was to meet it, and he sought to stifle any further objections to his proof of the identity of nervous and electrical currents by tetanizing the nerve without electricity. ${ }^{60}$ In this he was sorely disappointed. His equipment failed to detect any diminution in the nervous current. He tried every stimulus he knew: blows, burns, irritants, poisons - none deflected the needle. Even strychnine, which had given excellent results in muscle, produced only a suggestion of a swing, and he repeated the strychnine experiment forty-two times. ${ }^{61}$

He faced two options: either he could forget the phenomenon of negative variation entirely, and with it his six-year effort at proving the identity of nervous signals and electricity, or he could find a way out of his quandary. He chose the latter. Reasoning through his failure, he remembered that muscles tetanized with strychnine evoked only a tenth the response of muscles tetanized with electricity. The best deflection that he had seen using the magneto-electromotor on a nerve was five degrees. Strychnine was never going to give him any results, not with his present equipment.

This was in 1847. By then, the first volume of his treatise on animal electricity had already gone to press, and the printer was asking for the second. ${ }^{62} \mathrm{Du}$ Bois-Reymond nevertheless decided to stop writing and to build a far more powerful galvanometer. ${ }^{63}$ After consulting with local instrument-makers Boetticher and Halske, he settled on an ambitious design. The new model was to possess a mile of wire. At 24,160 turns, this was nearly four times as many as his previous instrument, making it one of the most sensitive devices in existence. ${ }^{64}$ Power did not come cheap; it took him weeks to wind

59 Du Bois-Reymond, op. cit. (6), ii.i, 430-1, 563-4.

60 Du Bois-Reymond, op. cit. (6), ii.i, 473-5.

61 Du Bois-Reymond, op. cit. (6), ii.i, 475; Emil du Bois-Reymond to Carl Ludwig, 4 January 1848, op. cit. (45), 4-6, 5 .

62 UTE, $1: \operatorname{lv} ; 2.1: 494-5$.

63 Du Bois-Reymond, op. cit. (6), i, p. lv; ii.i, 494-5.

64 Du Bois-Reymond, op. cit. (6), ii.i, 507. 
the armature. ${ }^{65}$ Calibration was equally maddening. To protect the delicate needles from air currents, the device was enclosed within a glass bell. For each adjustment, he had to remove the bell, make his correction, replace the bell and observe the effect. This process exposed the mechanism to dust, which took hours to remove with a cotton swab. Near despair, he returned to Halske and had fittings added that allowed fine tunings with the bell in place. ${ }^{66}$ Compensation for geomagnetism then only required the turn of a screw.

The reconfigured instrument performed beautifully. Current from the ischiadicus nerve pegged the needle on the initial swing and held it at a constant deflection of forty to fifty degrees. ${ }^{67}$ Compared to his previous galvanometer, the new device 'seemed like a compound microscope instead of a doublet ... [everything] is easier to see'. ${ }^{68} \mathrm{Du}$ BoisReymond checked himself from getting carried away with enthusiasm and made sure to repeat his earlier experiments on the nerve. He was relieved to see that his findings held.

Nevertheless, detecting the nervous signal without the benefit of electrical tetanization remained exceedingly difficult. During the weeks that he devoted to the experiment, he considered every aspect of his equipment and protocol, but there was nothing he could think of to improve. Negative variations produced by non-electrical means were tiny. Their observation lay at the 'limits of our perceptive ability'. Du BoisReymond found it nearly impossible to distinguish the signal from the natural swing of the galvanometer needle. ${ }^{69}$ At only two points on the arc of descent did the needle come to rest; to make the variation visible, he had to time the onset of tetanus to coincide with these short periods of motionlessness. ${ }^{70}$ 'However this may be', he coolly remarked, 'the experiment occasionally succeeds. One then has the sight - which, mind you, was worth some effort - of seeing the needle, rather than the gastrocnemius, twitch at the moment of tetanic innervation' ${ }^{71}$ His first success came on 18 November 1847 . Using strychnine, he obtained a deflection of one to four degrees. He also managed to witness the effect with other means of tetanization that did not involve electricity - for example, with red-hot irons or pinwheel spurs - but his most spectacular results were produced with explosives. In this variant he coated the nerve with a thin layer of wet gunpowder. Watching the galvanometer needle through a telescope, he ignited the train. As long as the pads of blotting paper were shielded from sparks, the experiment worked well. ${ }^{72}$

65 Du Bois-Reymond could wind a hundred turns in half an hour. Emil du Bois-Reymond to Carl Ludwig, 4 January 1848 , op. cit. (45), 4-6.

66 Du Bois-Reymond, op. cit. (6), ii.i, 490-1.

67 Du Bois-Reymond, op. cit. (6), ii.i, 492.

68 Du Bois-Reymond, op. cit. (6), ii.i, 495.

69 Und ich kann mir, muß ich bekennen, weder von dem experimentellen Geschick noch von den Hülfsmitteln eine Vorstellung machen, für und durch welche diese Beobachtungen von der Grenze unserer Wahrnehmungsfähigkeit, wo sie jetzt stehen, jemals der gewöhnlichen Mitte feinerer thatsächlichen Prüfungen näher gebracht werden sollen.

Du Bois-Reymond, op. cit. (6), ii.i, 508.

70 Du Bois-Reymond, op. cit. (6), ii.i, 508-9.

71 'Wie dem auch sei, der Versuch glückt von Zeit zu Zeit nach Wunsch. Man hat alsdann den Anblick, der allerdings einiger Bemühung werth war, im Augenblicke der tetanischen Strichnininnervation statt des Gastrocnemius die Magnetnadel zucken zu sehen'. Du Bois-Reymond, op. cit. (6), ii.i, 512.

72 Du Bois-Reymond, op. cit. (6), ii.i, 519. 


\section{The crucial experiment}

Much has been made of persuasion in the sciences. Here, too, du Bois-Reymond was adept. From childhood on he had been trained to associate thinking and exposition. Truth existed for him only in clarity. Paraphrasing Darwin, we could say that all of du Bois-Reymond's work reduced to one long demonstration. To this end he devised a final experiment, one that sought to compel assent in all who witnessed it. This was his famous demonstration of voluntary tetanic current in a living person - in other words, the electrical manifestation of the human will. This demonstration was as simple and as striking as any in physiology yet, as we will see, the very power of his method caused it to fail. Rather than winning universal acclaim, du Bois-Reymond's experimentum crucis elicited a series of doubts that ultimately caused him to revise his deepest expectations of science.

$\mathrm{Du}$ Bois-Reymond knew that the existence of the negative variation would carry more weight if he could demonstrate it in people. Since he wished to show that life obeyed the laws of physics, what better place than in the body of the only creature deemed to possess a soul? To his mind, an experiment in a conscious subject would render absolutely plain the identity of nerve currents and electricity. It was one thing to claim that frog nerves acted in the same way as human nerves; it was another to prove it.

Early on in his researches, du Bois-Reymond had learned that direct measurements of electricity in living subjects were exceedingly difficult. The main problem was skin, a factor absent in frog preparations. Skin added current and resistance to the circuit and, to make matters worse, the values of these currents and resistances seemed to depend on a variety of other conditions, including the duration of contact with the conducting fluid, the temperature of the body, the degree the skin was stretched and the conductivity of the electrolyte. ${ }^{73}$ All these sources of interference made it impossible for him to estimate the strength of the muscle current - and without this estimate, there was no way he could determine how much that strength varied. ${ }^{74}$ His answer was to measure the signal indirectly, employing the famed 'method of compensation'. The technique was simple: he configured two elements of a circuit so that their currents opposed, or 'compensated', and then measured the difference with a galvanometer. As long as the voltages across each element remained the same, the galvanometer needle kept still. At the slightest imbalance, however, the needle swung. This electrical technique, popularized by the British inventor Charles Wheatstone in 1843, was well known to physicists; du Bois-Reymond's innovation was to apply it to the study of organic materials, in this instance, to his own body. Here, his right and left arms acted as the balanced elements of the circuit. The symmetry of the arrangement enabled his muscle and skin currents to cancel, leaving the galvanometer free to detect any remaining difference current, or negative variation, between his limbs.

As usual, du Bois-Reymond refined his apparatus to eliminate all potential error. Since electrodes gave rise to contact electricity, he used conducting vessels as the

73 Du Bois-Reymond, op. cit. (6), ii.ii, 186-268.

74 Du Bois-Reymond, op. cit. (6), ii.ii, 245, 277. 


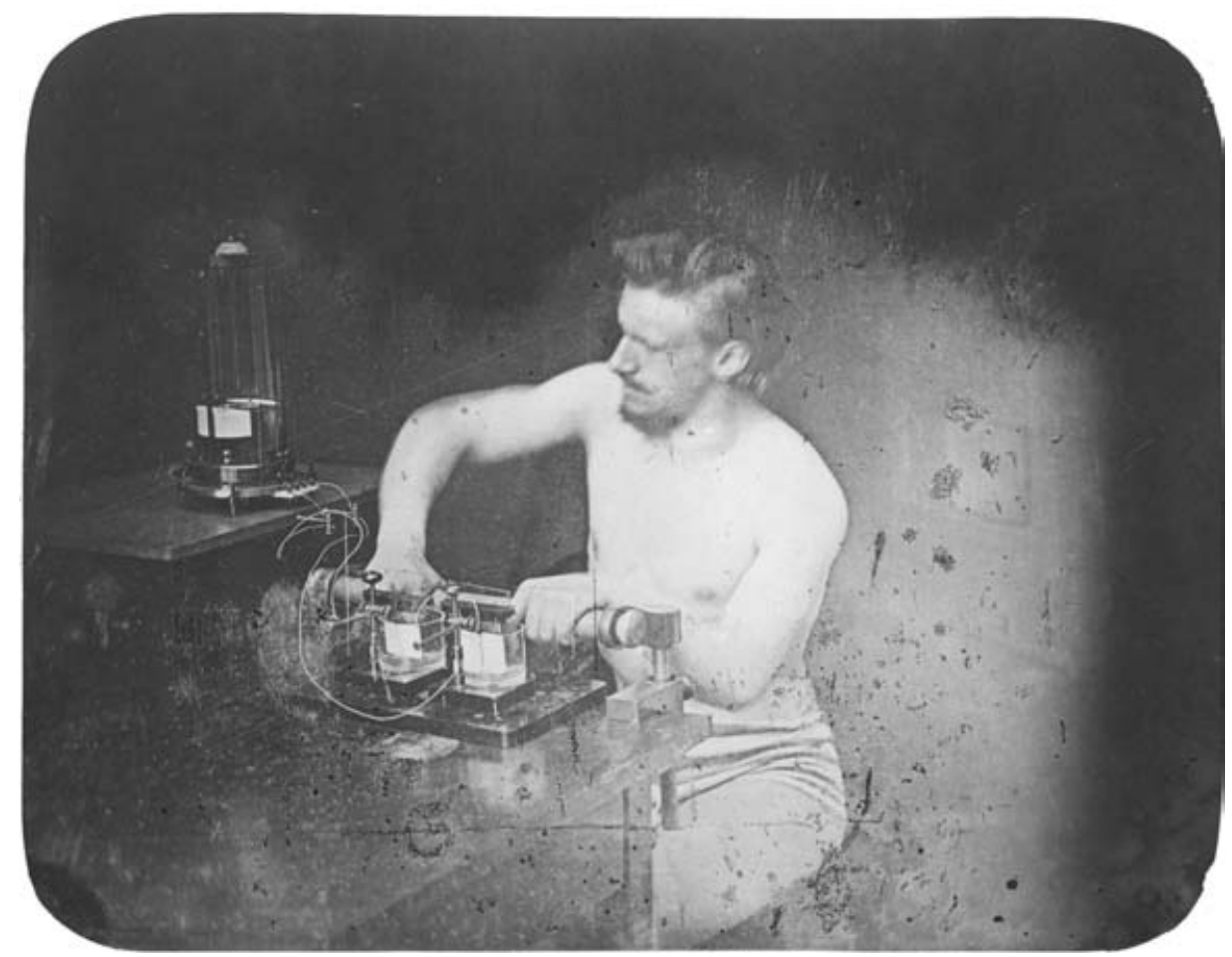

Figure 9. Photograph of Paul du Bois-Reymond, Emil's younger brother, demonstrating tetanic currents in his own body. The galvanometer used to detect the signal rests on a separate table by his right arm, the one he appears to be tensing. Note how the experimenter dips only his index fingers into the conducting vessels. The idea for the steadying wooden bar may have come from Emil du Bois-Reymond's experience with gymnastic equipment.

interface between his hands and the galvanometer. Cotton gloves kept electrolyte from lapping against his skin. Varnished wooden dowels inside the vessels let him hold himself steady. Finally, he avoided sustaining any cuts or abrasions that might imbalance the circuit. With these precautions, the demonstration became straightforward. Du Bois-Reymond washed his hands, immersed them in the saline, and grasped the dowels. With both arms relaxed, he waited for the galvanometer needle to rest at zero. Suddenly and powerfully, he contracted all the muscles in one arm. The needle, as predicted, deflected instantly in response (Figures 9 and 10). ${ }^{75}$

The main difficulty in achieving good results lay with the experimental subject. It was no 'child's play', as he put it, to tense one arm 'hard as wood' while leaving the other absolutely limp. 'Young men who have performed physical training will not find this difficult ${ }^{9}{ }^{76}$ Nevertheless, athletic talent was not a precondition to success, and du

75 Du Bois-Reymond, op. cit. (6), ii.ii, 278-88, 295-6. Initial success came on 3 August 1846. Laboratory notebooks, 1843-9, dB-R papers, K. 10, Nr. 7, Bl. 24-7, witnessed by the Physical Society.

76 'Jungen Männern, die Leibesübungen getrieben haben, wird dies nicht schwer'. Du Bois-Reymond, op. cit. (6), ii.ii, 295. 


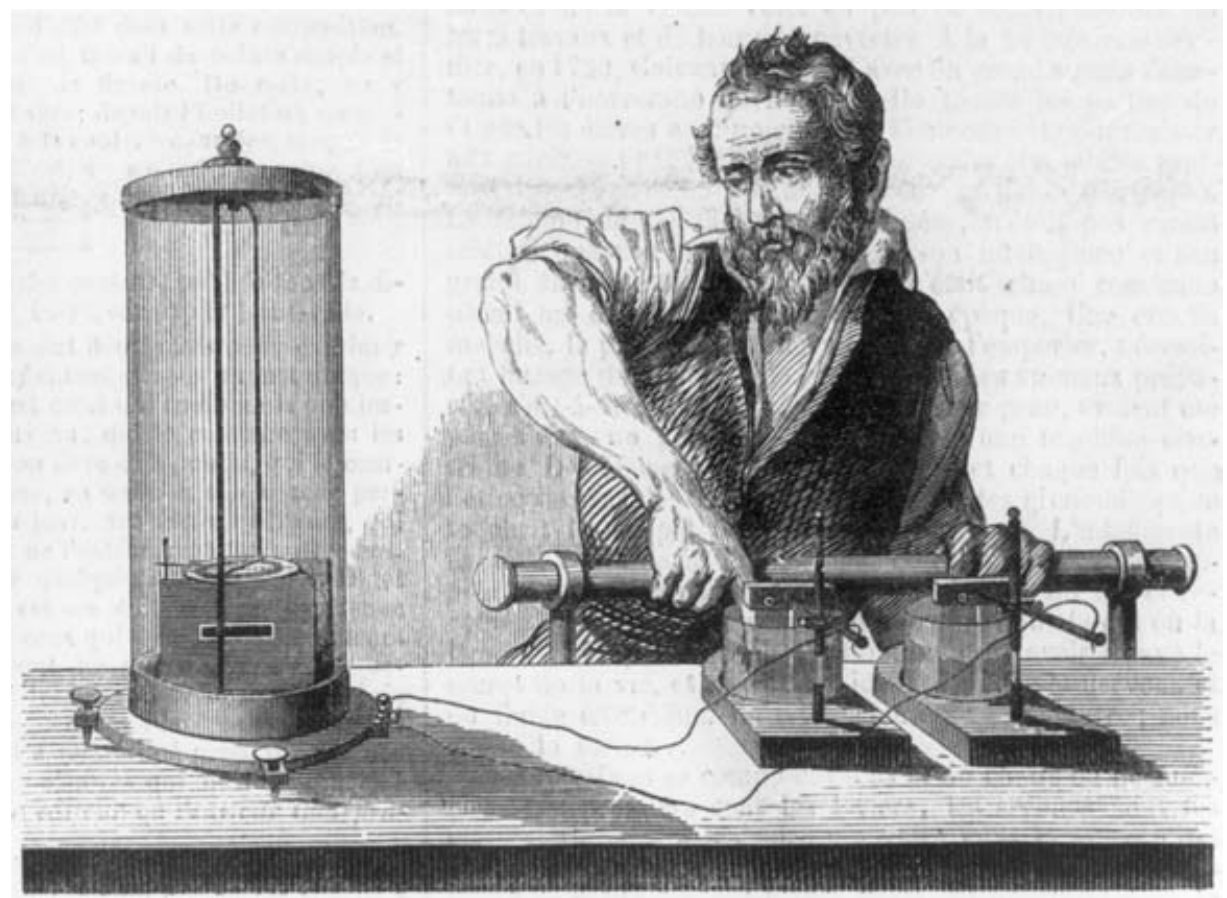

Figure 10. Du Bois-Reymond's voluntary tetanic current demonstration as portrayed in L'Illustration, Saturday 15 June 1850.

Bois-Reymond eventually performed the experiment on more than fifty persons, 'most belonging to the educated classes' ${ }^{77}$

The first to learn of the achievement were du Bois-Reymond's friends and colleagues. News travelled quickly, and soon visiting scientists asked to witness the demonstration. The greatest honour came in September 1847, when Alexander von Humboldt, who was seventy-eight years old, climbed the stairs to du Bois-Reymond's apartment to see the experiment for himself. ${ }^{78}$

Not long thereafter du Bois-Reymond's troubles with the French began. In April 1849 Humboldt sent Arago a description of du Bois-Reymond's finding. ${ }^{79}$ Humboldt had already mentioned the discovery to his friend before, but this time Arago was impressed. ${ }^{80}$ The next opportunity he had, Arago read Humboldt's letter to the Academy

77 'Die meisten gehörten dem gelehrten Stande an'. Du Bois-Reymond, op. cit. (6), ii.ii, 296.

78 Du Bois-Reymond, op. cit. (6), ii.ii, 308-9; Emil du Bois-Reymond to Eduard Hallmann, 17 Juni 1846, op. cit. (1), 125-7, 126.

79 He may have been motivated by a letter sent by Carlo Matteucci summarizing his latest findings. Carlo Matteucci to Alexander von Humboldt, 23 April 1849, SD F1e 1840 (2) Bl. 10-13, passed on to Emil du BoisReymond. Rudolf Wagner had also recently touted the Italian scientist, whom he met in Pisa and Tuscany. Rudolf Wagner to Emil du Bois-Reymond, 10.1.1849, SD 3k 1854 (5) Bl. 9-10.

80 Alexander von Humboldt to Emil du Bois-Reymond, [Berlin] Sonnabend [12 May 1849] (\#19), op. cit. (7), 88-9. 
of Sciences. ${ }^{81}$ The Academy reacted with disbelief and sent word back to Berlin requesting an explanation of du Bois-Reymond's results. ${ }^{82}$ At this point Humboldt informed du Bois-Reymond of the uproar he had caused. He asked whether there was an account of the experiment that he could translate for the Academy and suggested that $\mathrm{du}$ Bois-Reymond discuss the matter with him. ${ }^{83}$ This du Bois-Reymond did, letting Humboldt know that he had never published more than a note on his discovery, but nonetheless inviting him to witness it again all the same. ${ }^{84}$ On 15 May 1849, in the presence of Helmholtz and Müller, Humboldt succeeded in deflecting the needle of du Bois-Reymond's galvanometer. ${ }^{85}$ Two days later Humboldt sent a letter to Arago attesting to this fact and enclosed a short description of the experiment that du BoisReymond drafted for the Academy's benefit. ${ }^{86}$

César Mansuète Despretz and Antoine César Becquerel were the first scientists who attempted to reproduce du Bois-Reymond's results. They both failed, primarily because of the insensitivity of their galvanometers, but also because they ignored the laboratory protocol that du Bois-Reymond had detailed in his Investigations. Despretz concluded that du Bois-Reymond had been deceived by contact electricity and went on to question the rest of his work. ${ }^{87}$ Becquerel, who attributed the effect to polarizations of charge on the skin and on the platinum plates, also dismissed it as spurious. ${ }^{88}$ The controversy was then picked up by the Journal des débats, a popular intellectual daily. Léon Foucault, who was science editor, wrote a sarcastic review of the experiment in which du Bois-Reymond appeared to have asserted the possibility of deflecting the galvanometer needle by willpower alone. Such a claim, Foucault argued, 'approaches the miraculous and bears the stamp of the German mind that formulated it' ${ }^{89}$ Foucault

81 M. Du Bois est l'habile expérimentateur qui, le premier et le seul, a réussi à faire dévier une aiguille astatique par la volunté de l'homme, c'est-à-dire par le courant électrique que produit l'effort musculaire, la tension de nos membres. Cette déviation s'opère à de grandes distances, et cesse dès qu'à on ne tend plus le muscle.

F. Arago, 'Extrait d'une lettre de M. de Humboldt à M. Arago', Comptes rendus (30 avril 1849), $28,570$.

82 Alexander von Humboldt to Emil du Bois-Reymond, [Berlin] Sonnabend [12 May 1849] (\#19), op. cit. (7), 88-9.

83 Alexander von Humboldt to Emil du Bois-Reymond, op. cit. (82).

84 Du Bois-Reymond, op. cit. (6), i, p. xv; C. G. Ehrenberg [Report of Emil du Bois-Reymond's finding], Monatsberichte der Königlichen Preußischen Akademie der Wissenschaft zu Berlin (26 October 1848), 349-69, 362.

85 Emil du Bois-Reymond to Carl Ludwig, 17 May 1849, op. cit. (45), 32-6, 34; du Bois-Reymond, op. cit. (6), ii.ii, 309.

86 Alexander von Humboldt to François Arago, 17 mai 1849, Comptes rendus (21 mai 1849), 28, 643; E. du Bois-Reymond, 'Nouveaux détails sur les expériences de M. E. du Bois Reymond concernant l'électricité développée par le fait de la contraction musculaire', Comptes rendus (1849), 28, 641-3.

87 C. M. Despretz, 'Note relative à l'électricité developpée dans la contraction musculaire, etc.', Comptes rendus (1849), 28, 653-8; C. M. Despretz, 'Note relative to the electricity developed by muscular contraction', The London, Edinburgh and Dublin Philosophical Magazine (1849), 35, 55-9; du Bois-Reymond, op. cit. (6), ii.ii, 309-11.

88 A. C. Becquerel, 'Note relative au developpement de l'électricité dans l'acte de la contraction musculaire', Comptes rendus (1849), 28, 663-4.

89 'Le simple énoncé est déjà fort suspect; il vise au merveilleux et porte l'empreinte de l'esprit allemand qui l'a formulé'. L. Foucault, 'Académie des sciences: séances des 21 et 28 mai', Journal des débats politiques et littéraires, Feuilleton, vendredi, 1er juin 1849. 
reminded his readers that none of the scientists at the Academy had been able to verify du Bois-Reymond's finding, and that its status remained, at best, in need of further experimental confirmation.

Humboldt passed a copy of Foucault's article on to du Bois-Reymond and advised him not to take it amiss:

I am not really afraid that Becquerel's denial and the coarse jokes of Foucault, who hates everything German and me personally, will make you too unhappy. You always spoke of a voluntary muscle movement, never of a command of the needle. You see that Becquerel also deals sharply with Faraday. We, who have seen it, are not shaken by it ... Send me back the journal tomorrow. ${ }^{90}$

But du Bois-Reymond did take the French criticism amiss and, according to his version of the story, so did his patron. It now became a question of national honour, for as du Bois-Reymond put it, 'Humboldt could not justifiably let such a disparagement of his reputation, where additional emphasis had been placed on the German origin of the facts contested, go unavenged. ${ }^{91}$ Humboldt wrote to Mitscherlich, asking him to lend his support, and on 6 June Mitscherlich, Humboldt and Heintz met in du BoisReymond's apartment to witness yet another performance of the experiment. ${ }^{92}$ Humboldt then composed a second letter to Arago reaffirming his belief in the validity of du Bois-Reymond's result and drawing attention to the fact that it had been observed by several reputable scientists. The letter also reminded the Academy that, after half a century of research in animal electricity, it would take more than a couple of failed experiments and editorial wisecracks to shake him of his convictions. ${ }^{93}$ 'Following this letter', du Bois-Reymond commented, 'the attackers at least partly withdrew from some of their positions'. ${ }^{94}$ But Humboldt continued to be bothered by the attitudes of

90 Ich fürchte nicht daß das Läugnen von M. Becquerel und die groben Scherze des H. Foucault, der alles Deutsche und mich persönlich haßt, Sie sehr unglücklich machen werden. Sie haben immer von willkürlicher Muskelbewegung gesprochen, nie von einem Commandiren der Nadel. Sie sehen, daß Becquerel den Faraday auch nicht süß behandelt. Uns die wir gesehen erschüttert das nicht. ... Schicken Sie mir morgen die Zeitschr. zurück.

Alexander von Humboldt to Emil du Bois-Reymond, [Berlin] Montag [4 June 1849] (\#21), op. cit. (7), 93.

91 'Eine solche Verunglimpfung seines Ansehens, wobei noch dazu ein Nachdruck auf den deutschen Ursprung der angefochtenen Thatsache gelegt wurde, konnte $v$. Humboldt nicht füglich ungeahndet hingehen lassen'. Du Bois-Reymond, op. cit. (6), ii.ii, 311.

92 Alexander von Humboldt to Emil du Bois-Reymond, 6 June 1849 (\#22), op. cit. (7), 94, including a letter from Eilhard Mitscherlich to Alexander von Humboldt, 6 June 1849; du Bois-Reymond, op. cit. (6), ii.ii, 311.

93 Ni les plaisanteries des rédacteurs de certains journaux sur la crédulité allemand, ni les résultats négatifs obtenus jusqu 'ici par deux physiciens, habiles expérimentateurs, n'ont ébranlé mes convictions à l'égard de l'influence volontaire de l'action musculaire sur le mouvement et la direction de l'aiguille astatique du galvanomètre.

A. von Humboldt, 'Note sur les expériences de M. Du Bois-Reymond', Comptes rendus (1849), 29, 8-9.

94 'Die Angreifer zogen nach diesem Briefe wenigstens zum Theil ihre Stellungen etwas zurück'. Du BoisReymond, op. cit. (6), ii.ii, 312; Alexander von Humboldt to Emil du Bois-Reymond, Potsdam, Sonntag [9 July 1849] (\#24), op. cit. (7), 95, containing a copy of 'Influence de la volonté sur l'électro-magnétisme', La Lancette française: Gazette des hôpitaux civils et militaires (1849), 1, 311; L. Foucault, 'Académie des sciences: séance du 9 juillet', Journal des débats politiques et littéraires, Feuilleton, 12 juillet 1849. 
the French press, and du Bois-Reymond's indignation showed in his history of the period:

Other than that, nothing more was heard in France of my experiment, only that Ducros took interest in a man who had been known for years to the readers of the Comptes rendus through countless articles which repeatedly made wild claims in the field of electrotherapy. This man caused the multiplier needle to swing, not only by means of sensation, but also by means of thought, to wit, arithmetical operations. The swings are supposed to be greater the more complex the operation. The Academy did not scorn taking note of this indescribable achievement. ${ }^{95}$

Du Bois-Reymond's opinion of electrophysiology elsewhere in Europe was only slightly more charitable. ${ }^{96}$ The fact that no one in Britain, Switzerland, Germany and Italy had managed to duplicate his experiment merely demonstrated the level of ignorance and incompetence in his field. Whether he might have shared any responsibility for the failures of his colleagues was not an issue he discussed. He could have suspected that his treatise, which consisted of hundreds of pages of technical German, made difficult reading, and that few had the time and the will to master its complexities. ${ }^{97}$ But this consideration was moot; du Bois-Reymond knew that voluntary

95 Im Übrigen aber verlautete seitdem in Frankreich nichts von meinem Versuch, nur daß Ducros sich seiner annahm, ein Mann, der seit Jahren den Lesern der Comptes rendus bekannt war durch seine in zabllosen Aufsätzen stets von Neuem vorgebrachten ausschweifenden Behauptungen vornehmlich auf dem Felde der Elektrotherapeutik. Dieser brachte es bald dahin, nicht nur durch den Vorgang des Empfindens, sondern sogar durch den des Denkens, durch arithmetische Operationen nämlich, die Multiplicatornadel in Schwankungen zu versetzen, die um so heftiger sein sollten, je verwickelter die Operation. Die Akademie verschmähte nicht, Kenntniß von diesen schwer zu bezeichnenden Leistungen zu nehmen ...

Du Bois-Reymond, op. cit. (6), ii.ii, 312; Ducrois [Communication of electrophysiological experiment], Comptes rendus (1849), 28, 677; idem, 'Expériences sur les courants électrophysiologiques chez l'homme et les animaux', Comptes rendus (1849), 29, 16; idem, 'Suite de ses expériences sur les courants électrophysiologiques', Comptes rendus (1849), 29, 26; idem, 'Suite de ses recherches sur les courants électrophysiologiques', Comptes rendus (1849), 29, 57-8.

96 Du Bois-Reymond, op. cit. (6), ii.ii, 312-21. Cf. Gustav Karsten to Emil du Bois-Reymond, 12 October 1849, SD La 1859 (9) Bl. 28-9.

97 Reviews of the work were mixed. Physicians especially thought it exceptional: 'Nun woblan, hier ist ein Werk ächt deutschen Geistes und Fleisses, und verdient irgend eine Schrift aus dem letzten Jahre, als ein Würdiger Repräsentant der deutschen Richtung in den exacten physiologischen Wissenschaften aufgestellt zu werden, so ist es das vorliegende'. J. Bergson, Review of Untersuchungen über thierische Elektricität, by Emil du Bois-Reymond, Neue Zeitung für Medicin und Medicinal-Reform [Nordhausen] (19 April 1849), 1, 259-63. Heidenreich considered the sheer mass of material overwhelming. F. W. Heidenreich, 'Bericht über die Leistungen in der physiologischen Physik', Jahresbericht über die Fortschritte der gesammten Medicin in allen Ländern im Jahre 1848 (ed. Dr. Cannstatt and Dr. Eisenmann), Erlangen, 1849, i [Biologie], 7-8. Ludwig also thought the book outstanding, but found it difficult. Carl Ludwig to Jacob Henle, 22 November 1848, in A. Dreher, 'Briefe von Carl Ludwig an Jacob Henle aus den Jahren 1846-1872', inaugural dissertation, Ruprecht-Karl-Universität [Heidelberg], 1980, 56-60, 59. Wagner attended Weber's lectures to understand it. Rudolf Wagner to Emil du Bois-Reymond, 6 May 1850, SD 3k 1854 (5) Bl. 20-1. Faraday could not read it at all. Michael Faraday to Emil du Bois-Reymond, 15 January 1850, SD F1 e 1831 (2) Bl. 8-9. Auguste de la Rive gave his copy to Lord Byron's daughter Ada. Auguste de la Rive to Emil du Bois-Reymond, 21 October 1849, SD B 1840 (1) Bl. 12-3. Frau von Reichenbach, the wife of a Viennese industrialist, was seen reading it daily in her castle. Ernst Brücke to Emil du Bois-Reymond, Wien 16/I 50 [\#27], E. W. von Brücke, Briefe an Emil du Bois-Reymond (ed. H. Brücke, W. Hilger, W. Höflechner and W. W. Swoboda), 2 vols., Graz, 1978, i, 29-30. 
tetanus produced deflections of only two degrees in a normal galvanometer, and since he alone possessed the instrument with the power to perform the experiment, his finding could never be reproduced. ${ }^{98}$ To prove the existence of the negative variation in a human being, he would have to show it to the world himself.

\section{Paris in the spring}

The world meant Paris, and so on 15 March 1850, after a semester of teaching at the art academy and saving his money, du Bois-Reymond followed Magnus's advice and left for France. By then, scientists from Berlin had made Paris into a site of pilgrimage, and the thought of making the journey put du Bois-Reymond in high spirits. ${ }^{99} \mathrm{He}$ was accompanied by Werner Siemens, who had come to demonstrate his version of the telegraph, and they stayed in the same Hotel du Jardin des plantes where Müller had stayed with Jacob Henle nineteen years earlier. ${ }^{100}$ Success in Paris meant a great deal to the two young men. For Siemens, it could win him government contracts for his engineering business, and for du Bois-Reymond, the favour of a new scientific community. Political reaction had stalled his career in Germany and so, no doubt encouraged by his father, du Bois-Reymond hoped to use his name, his eloquence and his experiment to establish himself in France. ${ }^{101}$

Du Bois-Reymond kept a travel diary during his trip to Paris, and this source, combined with his correspondence, gives a near daily account of his activities in the six weeks that he spent in the capital. ${ }^{102}$ Except for descriptions of scientific apparatus or experiments, he made entries in French, indicating a willingness to attune his thinking to that of his hosts. His effort paid off; so great was his command of French that many Parisians flattered him by assuming him to be a native. ${ }^{103}$ Within days of his arrival, the Academy of Sciences welcomed him to their sessions, and even though his entry had been facilitated by letters of recommendation, the number and the stature of Parisian scientists who wanted to make his acquaintance impressed him. ${ }^{104}$ Most were members

98 Du Bois-Reymond, op. cit. (6), ii.ii, 316; Rudolf Wagner to Emil du Bois-Reymond, 10 January 1849, SD 3k 1854 (5) Bl. 9-10. Even du Bois-Reymond's friends had trouble reproducing his experiments; mechanics were scarce in Berlin, with the best, Halske, now devoting most of his attention to the telegraphy business that he founded with Siemens. Emil du Bois-Reymond to Carl Ludwig, 29 December 1849, op. cit. (45), 51-2.

99 The evening before he left he released his frogs downtown in order to watch the reaction of the ladies. He did not mind losing his collection, as he could always order more from the 'Institute of Berlin Street Urchins'. E. Rosenberger, Felix Du Bois-Reymond, Berlin, 1912, 282-3.

100 W. von Siemens, Lebenserinnerungen, 5th edn, Berlin, 1916, 85-7.

101 Emil du Bois-Reymond to Frau Johannes Müller, 4 April 1850, reprinted in W. Haberling, 'du BoisReymond in Paris 1850', Deutsche medizinische Wochenschrift (5 February 1926), 52, 251-2.

102 DB-R papers, K. 1, M. 7.

103 Emil du Bois-Reymond to Frau Müller, 4 April 1850, op. cit. (101).

104 Emil du Bois-Reymond to Frau Müller, 4 April 1850, op. cit. (101); Lundi 18 Mars [1850], dB-R papers, K. 1, M. 7, Nr. 2 (subsequently Travel diary), Bl. 2r. Du Bois-Reymond listed François Arago, JeanBaptiste-Léonce Elie de Beaumont, Antoine César Becquerel, Claude Bernard, Jean Baptiste Joseph Dieudonné Boussingault, Louis François Clément Bréguet, Auguste de la Rive, César Mansuète Despretz, Louis Michel François Doyère, Guillaume Benjamin Armand Duchenne, Alphonse Dulong, Jean Baptiste André Dumas, Louis Isidore Duperrey, Pierre Antoine Favre, Armand Hippolyte Fizeau, Pierre Flourens, François 
of the Academy of Sciences or the Philomatic Society, where du Bois-Reymond attended meetings. He also accepted invitations to witness experiments, visit museums, go sightseeing, take walks, have coffee and meet privately, as well as socializing more generally at balls, dinner parties and other functions. In short, he was received by French scientific society.

Paris dazzled. Writing from his hotel to Carl Ludwig, du Bois-Reymond raved, 'You can tell what the city is like from the fact that, blasé Berliner that I am, I feel quite crushed the first few days. It is indescribably grand and mighty. ${ }^{105}$ But despite his admiration, du Bois-Reymond could not help but notice a gulf between him and the French. Like the unseasonable weather, Parisians were cold. Berlin had often struck west and south Germans as being unfriendly, but Paris was infinitely worse. The first trait that he encountered was a sense of universal mistrust. Everyone sought to exploit their own advantage wherever they could, the fields of art and science offering no exception. Educated men did not fraternize as much as they did in Berlin, and it was much less common for strangers to receive private invitations, even with the best recommendations. Du Bois-Reymond also remarked upon the particular dearth of female company; ten days after his arrival, he had only really spoken with the fisherwoman who sold him his frogs. The French themselves admitted how little they truly enjoyed life, and where once their gaiety and esprit might have led them to forget this, now they had become serious and dull. Du Bois-Reymond animadverted that any thought that he had once entertained of settling in Paris had now vanished entirely. ${ }^{106} \mathrm{He}$ had been shown the forms of a great nation, but they were forms lacking in depth and substance.

It would be easy for us to dismiss this criticism of French society as the sour grapes of a rejected foreigner, but we should note that du Bois-Reymond expressed his opinions three days before he first demonstrated his experiments. ${ }^{107} \mathrm{He}$ may have had a premonition of how the French would respond to his work; if he did, he made no note in his diary. Perhaps the pressure to succeed coloured his attitudes. The last time that a physiologist from Berlin had presented his work in Paris was in 1831, when Müller proved Bell's law. ${ }^{108} \mathrm{Du}$ Bois-Reymond wanted to live up to this famous precedent, and so when he was invited to speak to the Academy of Sciences, he spent several days preparing his remarks. ${ }^{109} \mathrm{He}$ delivered his address over the course of two Mondays, on 25 March and 8 April. Fortunately, the original notes have survived. ${ }^{110}$ The first lecture began by outlining the history of animal electricity, with sections on eighteenth-century

Achille Longet, Charles Fréderic Martins, Henri Milne-Edwards, Théophile Joules Pelouze, Jean Victor Poncelet, Claude Servais Mathais Pouillet, Armand de Quatrefages, Henri Victor Regnault, Heinrich Daniel Ruhmkorff, Johann Silberman and Marcel Émile Verdet.

105 Emil du Bois-Reymond to Carl Ludwig, Paris, 9 April 1850, op. cit. (45), 57-8, 58.

106 Emil du Bois-Reymond to Frau Müller, op. cit. (103); 'Poissonnière', Jeudi 28 Mars [1850], Travel diary.

107 Dimanche 7 Avril [1850], Jeudi 11 Avril [1850], Travel diary.

108 Regarding the division of nerves between those that are motor and those that are sensory.

109 Dimanche 7 Avril [1850], Jeudi 11 Avril [1850], Travel diary.

110 DB-R papers, K. 1, M. 7, Nr. 3, Bl. 1-72. Du Bois-Reymond also delivered this address to the Philomatic Society on 30 March and 13 April. Travel diary; Emil du Bois-Reymond to Carl Ludwig, 9 April 1850, op. cit. (45), 57-8. 
experiments, Galvani's discovery, Volta's opposition, Humboldt's resolution of the debate and later advances by Nobili and Matteucci. No mention was made of Longet, perhaps out of deference, for du Bois-Reymond liked him. ${ }^{111}$ Du Bois-Reymond was also careful to give Italian scientists their due, but he did not hesitate to attack their weaknesses and, by implication, the weaknesses of their followers in France. He then turned to his own contributions, recounting the arduous process of identifying and eliminating sources of error in his instruments and drawing particular attention to the importance of non-polarizable electrodes. He concluded his introductory remarks with an analysis of polarization chemistry that emphasized the inferiority of Matteucci's method.

Du Bois-Reymond's French address followed the same plan as his German treatise, covering the background, methods and discoveries of animal electricity. Having reviewed the first two topics for his Parisian audience, he now turned to the third. The Academy had chosen a commission of François Magendie, Claude Servais Mathias Pouillet, César Mansuète Despretz, Antoine César Becquerel and Pierre François Olive Rayer to evaluate his claims, and for their benefit du Bois-Reymond summarized his previous work. He went back to the law of muscular current, briefly glossing what he meant by long-section and cross-section, and then described how he had observed the signal of negative variation both with and without electrical means of tetanization. $\mathrm{He}$ added that he had detected the phenomenon in nerves, muscles and limbs, and that his latest experiment simply confirmed in man what he had already seen in frogs. There he ended his first presentation.

Du Bois-Reymond recorded little in his diary of the Academy's reaction except to note that Magendie and Pouillet spoke to him afterwards, 'the former very rudely, the latter quite decently'. ${ }^{112}$ They must have told him that his speech was too long to serve as a formal report, for the next day du Bois-Reymond cut the entire historical and methodological introduction from his manuscript. ${ }^{113}$ The change was only to his benefit; the version received by the commission was a model of scientific style - short, clear and to the point. ${ }^{114}$

The same was true of his second lecture, which discussed the negative variation at greater length. The essence of the phenomenon, du Bois-Reymond reminded his listeners, was its dependence on the rate of change of the excitatory current. ${ }^{115}$ This fact explained several others that du Bois-Reymond proceeded to list. It was now evident,

111 Emil du Bois-Reymond to Carl Ludwig, 9 April 1850, op. cit. (45), 57-8; Emil du Bois-Reymond to Frau Johannes Müller, 4 April 1850, op. cit. (101). Longet had just published the second part of his Traité de physiologie, and as it was very well received, du Bois-Reymond may have thought it politic not to say anything against him. See the review by Leon Foucault, 'Académie des sciences', Journal des débats politiques et littéraires, Feuilleton, mercredi, 27 mars 1850; du Bois-Reymond preferred Ludwig's textbook, 'generations ahead of French conceptions'. Emil du Bois-Reymond to Carl Ludwig, 9 April 1850, op. cit. (45), 57-8.

112 'M. Magendie et Pouillet viennent me parler; le premier d'une façon très grossière, le second d'une manière fort honnète [sic]'. Lundi 25 Mars [1850], Travel diary.

113 His diary entry reads, 'Emasculated my report' - 'Châtré mon Mémoire'. Mardi 26 Mars [1850], Travel diary.

114 E. du Bois-Reymond, 'Note sur la loi du courant musculaire, et sur la modification qu'éprouve cette loi par l'effet de la contraction', Comptes rendus (25 mars 1850), 30, 349-52.

115 This law bears du Bois-Reymond's name. 
for example, why opening or closing a circuit produced muscular contractions: every make or break radically altered the current's steady state. In the same way, the frog's leg reacted to the merest amounts of electricity provided that the excitatory stimulus varied with suitable rapidity. And since tetanus was nothing other than a series of rapid muscular contractions, each producing a brief electrical discharge, they appeared as a negative variation when summed by the galvanometer. Little wonder Matteucci foundered in his efforts at measuring the work performed by the nervous principle transient currents could hardly do work. Matteucci, who was vague on most of the physics behind animal electricity, had also failed to appreciate the functional difference between the rheoscopic frog and the galvanometer. His confusion led him from any simple explanation of the 'induced' contraction just as it blinded him to the superiority of du Bois-Reymond's accomplishments (Figure 11). ${ }^{116}$

Du Bois-Reymond considered the second presentation to have gone well. ${ }^{117}$ The following day he sent Ludwig an enthusiastic letter that admitted how he had intended his address to subtly demolish Matteucci. ${ }^{118}$ Du Bois-Reymond's rhetoric had been effective; now every scientist in Paris wanted to see his experiments. He had prepared himself, having set up a small laboratory in his hotel room, and he assured Ludwig that he still had plenty of cards up his sleeve. ${ }^{119}$

\section{'Violent quarrel'}

Du Bois-Reymond would, in fact, come to need his aces, but it was Becquerel, not Matteucci, who raised the stakes. Becquerel's research in thermoelectricity had acquainted him with the difficulties in working with faint currents. He was convinced that any deflection of the galvanometer needle could be traced to errors in du BoisReymond's experimental design. When the Academy commission convened officially on Thursday, 11 April 1850, Becquerel voiced his objections: the deflection could well have been caused by inadvertent movement of the fingers, or by heat evolved by the muscles, or by perspiration secreted by the fingers during the effort of contraction. ${ }^{120}$

Du Bois-Reymond easily dismissed the first two points. It was a simple matter to insure immobility by bracing his fingers against the bottom of the conducting vessel. Furthermore, Helmholtz had already shown that tetanus raised muscular temperature

116 E. du Bois-Reymond, 'Note sur la loi qui préside à l'irritation des nerfs, et sur la modification du courant musculaire par l'effet de la contraction', Comptes rendus (1850), 30, 406-9.

117 Even Foucault suspended criticism. L. Foucault, 'Académie des sciences', Journal des débats politiques et littéraires, Feuilleton, 12 avril 1850.

118 Emil du Bois-Reymond to Carl Ludwig, 9 April 1850, op. cit. (45), 57-8.

119 For example, the following legend. When asked to demonstrate at the Academy, du Bois-Reymond replied that his German galvanometer was too delicate to be easily relocated, and the Académiciens should come to his hotel, else he would pack up and go to London, to which the French acquiesced and civilly declared that he was no German at all, but rather one of them. Rosenberger, op. cit. (99), 285.

120 Jeudi 11 Avril [1850], Travel diary; Emil du Bois-Reymond to Carl Ludwig, 26 August 1850, op. cit. (45), 59-61, 60; Emil du Bois-Reymond to Hermann Helmholtz, 25 August 1850, Dokumente einer Freundschaft. Briefwechsel zwischen Hermann von Helmboltz und Emil du Bois-Reymond, 1846-1894 (ed. Christa Kirsten, Herbert Hörz, Klaus Klauß, Wolfgang Knobloch, Marie-Luise Körner, Andreas Laaß and Siegfried Wollgast), Berlin, 1986, 98-100; du Bois-Reymond, op. cit. (6), ii.ii, 356. 


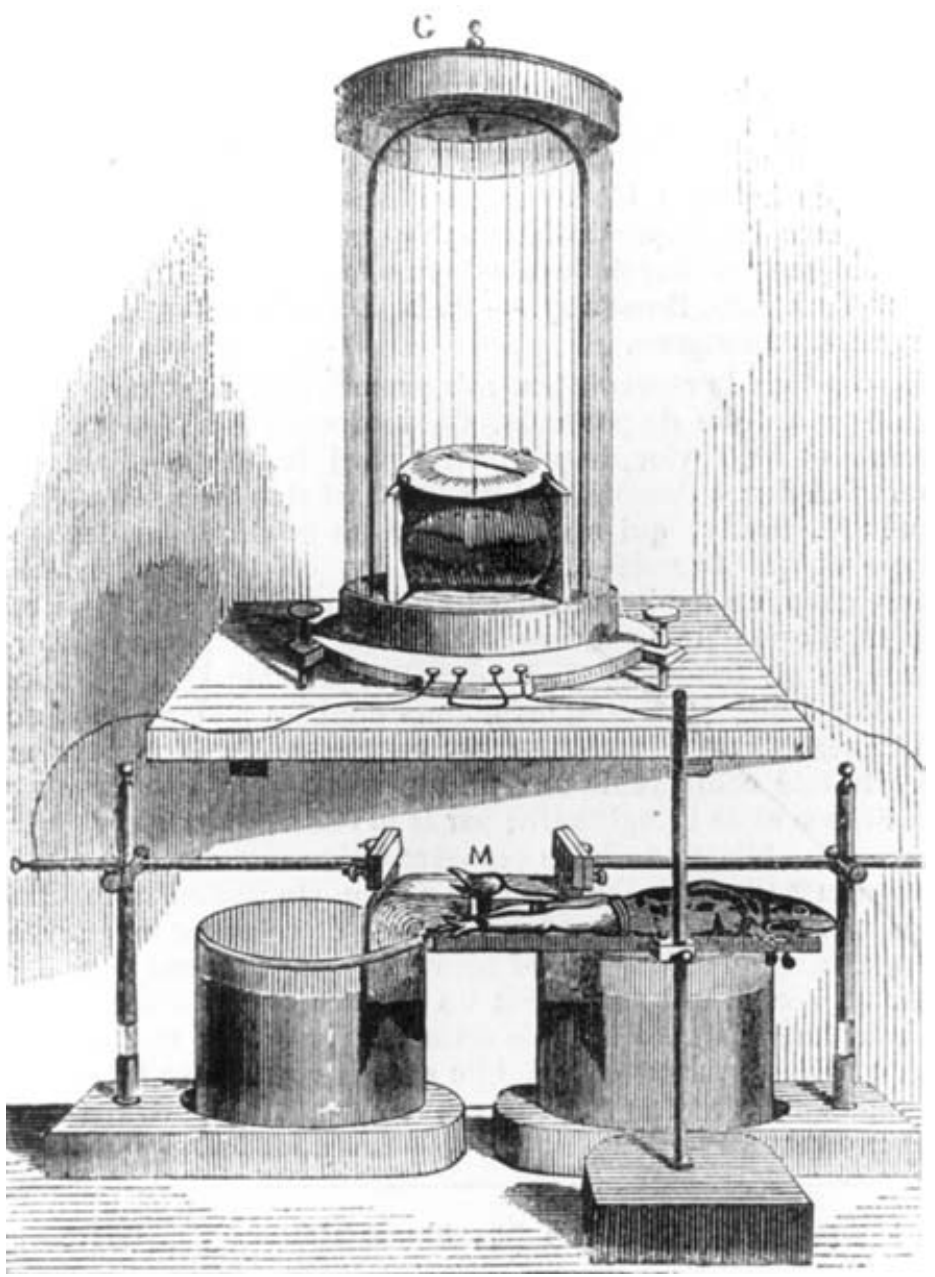

Figure 11. Protocol for demonstrating 'induced' muscle currents. The nerve of rheoscopic frog $M$ lies across the exposed leg of a live frog. The galvanometer records the negative variation in current derived from $M$ in response to the twitch of the live frog leg. The experiment serves as a half step between demonstrating artificially induced negative variations in prepared frog muscles (Figure 5) and voluntary induced negative variations in live human subjects (Figure 9).

by less than one to two tenths of a degree; an increase could not possibly generate the thermoelectricity necessary to deflect a galvanometer needle. ${ }^{121}$ As for the theory of perspiration giving rise to a current 'by virtue of a chemical action' - well, du BoisReymond considered this simply preposterous. ${ }^{122}$

121 Du Bois-Reymond, op. cit. (6), ii.ii, 354; Kremer, op. cit. (45), 293.

122 'En virtu d'une action chimique'. Emil du Bois-Reymond to Carl Ludwig, 26 August 1850, op. cit. (45), 60 . 
But Becquerel would not be cowed, and he decided to call du Bois-Reymond's bluff. Why not put the issue to an immediate test? Du Bois-Reymond could perform the experiment exactly as before, but with one important modification: instead of immersing his hands in the electrolyte before flexing his muscles, he was to immerse them afterwards. This way the effects of any perspiration would be made visible. Du BoisReymond looked around at the members of the commission and realized that he had no choice but to oblige. He dangled his hands over the conducting vessels, tensed one arm, and lowered his index fingers into the conducting fluid. To his horror, the needle deflected. ${ }^{123}$

Following this defeat, du Bois-Reymond tried to argue that the deflection merely demonstrated after-effects of tetanus, but Becquerel would not budge. He and du BoisReymond met three days later at du Bois-Reymond's hotel, presumably to settle their differences. As du Bois-Reymond set up the experiment, Becquerel paced back and forth, muttering, 'What I've done in electricity is enormous - enormous!'124 'Violent quarrel' was all that du Bois-Reymond remarked of their encounter in his diary. ${ }^{125} \mathrm{He}$ then tried to appeal to Magendie and Rayer, the physiologists of the commission, but Becquerel had already recruited them to his 'terrible factional opposition'. ${ }^{126}$ Finally, Pouillet, the director of the commission, suggested a means of resolving the dispute. Du Bois-Reymond could attempt the experiment with a small modification: a little sulphuric acid and potash was to be added to the conducting fluid to neutralize the effects of the perspiration. If the direction of the current then remained as it was, Becquerel's hypothesis would no longer be tenable. The next week du Bois-Reymond conducted the modified experiment before the Academy commission. The galvanometer needle moved all the way to the peg. ${ }^{127}$ Upon this success, he turned to Despretz and said, 'You see, Monsieur, I don't earn my bread by the sweat of my fingers.' 'Not bad for a German', came the reply. ${ }^{128}$ Becquerel failed to turn up for this performance. ${ }^{129}$

Du Bois-Reymond now believed himself to have been vindicated. His anxiety about French opinion lessened slightly during the remainder of his stay in Paris. ${ }^{130} \mathrm{He}$ still argued with Matteucci - this time over priority for the discovery of the negative variation - but he delivered his briefs to the Comptes rendus more in triumph than in protest. ${ }^{131}$ Since Matteucci never quite understood what he had observed, du

123 Du Bois-Reymond, op. cit. (6), ii.ii, 356.

124 'Ce que j'ai fait dans l'électricité est énorme - énorme!' Rosenberger, op. cit. (99), 286.

125 'Violente querelle'. Samedi 13 avril [1850], Travel diary.

126 Emil du Bois-Reymond to Carl Ludwig, 26 August 1850, op. cit. (45), 60.

127 Emil du Bois-Reymond to Carl Ludwig, 26 August 1850, op. cit. (45), 60; Emil du Bois-Reymond to Hermann Helmholtz, 25 August 1850, op. cit. (120), 98-100, 100.

128 'Vous voyez donc bien Monsieur, que je ne gagne pas mon pain à la sueur de mes doigts'. '- Pas mal pour un Allemand'. Emil du Bois-Reymond to Hermann Helmholtz, 25 August 1850, op. cit. (120), 100.

129 Vendredi 26 Avril [1850], Travel diary.

130 Emil du Bois-Reymond to his parents, 7 mai 1850, Staatsbibliothek Preußischer Kulturbesitz zu Berlin, Haus 2, Handschriftenabteilung, Depositorium Runge-du Bois-Reymond (subsequently Dep. 5), K. 11, Nr. 5.

131 C. Matteucci, 'Réclamation de priorité à l'occasion des communications récentes de M. Du BoisReymond, sur des recherches d'électricité', Comptes rendus (1850), 30, 479-80; E. du Bois-Reymond, 'Réponse à la réclamation de priorité de M. Matteucci', Comptes rendus (1850), 30, 512-15; idem, 'Seconde réponse à la réclamation de priorité de M. Matteucci', Comptes rendus (1850), 30, 563-6; C. Matteucci, 
Bois-Reymond contended, he forfeited any rights to priority. ${ }^{132}$ This may have been pushing things too far; Matteucci's experiments with the induced contraction had indeed been legitimate. Still, there was much to du Bois-Reymond's point that Matteucci could not assert something, deny it later, and then, on learning that he had been right all along, claim the original discovery as his own. ${ }^{133}$ As far as the Academy was concerned, Matteucci had made only two major discoveries, and these du Bois-Reymond never denied. ${ }^{134}$ He simply found it outrageous that Matteucci would also want to assume authorship for work that he had disparaged for so long. ${ }^{135}$

Du Bois-Reymond's confidence grew from his realization that German science really did match up to French. The achievement was not to be slighted. Du Bois-Reymond saw an impressive pace of work in Paris. Claude Bernard had succeeded in inducing artificial diabetes, Hippolyte Fizeau and Léon Foucault had each measured the speed of light, and Pierre Flourens had extended his research in brain function. ${ }^{136}$ But in other fields of investigation - particularly in the technical approaches to physics and physiology - Berliners led the way. For their part the French generally refused to acknowledge any German superiority. Siemens failed to secure orders for his telegraph, and Helmholtz's measurement of the velocity of the nervous signal met with 'the dumbest objections and doubts'. ${ }^{137}$ The Academy's evaluation of du Bois-Reymond was more positive, but it was apparent how reluctantly they lent their esteem.

\footnotetext{
'Réponse aux deux dernières lettres de M. du Bois-Reymond, insérées dans les nos 17 et 18 des Comptes rendus de l'Académie, et en général à toutes les observations faites par le même auteur sur quelque-unes de mes recherches d'électrophysiologie', Comptes rendus (1850), 30, 699-707; E. du Bois-Reymond, 'Troisième réponse à M. Matteucci', Comptes rendus (1850), 31, 91-5.

132 Du Bois-Reymond, 'Troisième réponse', op. cit. (131), 95-6.

133 Du Bois-Reymond, 'Troisième réponse', op. cit. (131), 95-6.

134 These were 1) an electric current directed from the interior to the exterior of the muscle, and 2) the induced contraction. C. Pouillet et al., 'Rapport sur les Mémoires relatifs aux phénomènes électrophysiologiques présentés à l'Académie par M. E. du Bois-Reymond (de Berlin)', Comptes rendus (1850), 31, 28-47, 34.

135 Matteucci was quite often confused about who had done what. On one occasion he credited du BoisReymond for work that he had never performed. E. du Bois-Reymond, 'Note by M. du Bois-Reymond on M. Matteucci's paper on electro-physiology', The London, Edinburgh and Dublin Philosophical Magazine and Journal of Science (1850), 37, 318-19. Matteucci has received more than generous treatment by historians of science. See Moruzzi, 'Work', op. cit. (24); Clarke and Jacyna, op. cit. (7); Trumpler, op. cit. (12). Even Rudolf Wagner, who was one of Matteucci's best friends in Germany, admitted that Matteucci had been dishonest towards du Bois-Reymond. Rudolf Wagner to Emil du Bois-Reymond, 29 December 1849, SD 3k 1854 (5) Bl. 17-8.

136 Du Bois-Reymond, samedi, 27 avril [1850]; lundi, 15 avril [1850]; jeudi, 11 avril [1850], Travel diary; Louis Clément Bréguet to Emil du Bois-Reymond, 16 mai 1850, dB-R papers, K. 1, M. 7, Bl. 1-2; L. Foucault, 'Académie des sciences: séances des 15 et 22 avril', Journal des débats politiques et littéraires, Feuilleton, 24 avril 1849; F. L. Holmes, Claude Bernard and Animal Chemistry: The Emergence of a Scientist, Cambridge, 1974; Clarke and Jacyna, op. cit. (7), Chapter 6.

137 'M. Siemens ayant soumis à l'Académie un très beau télégraphe alphabétique de son invention, son appareil est devenue sans retard l'objet d'un rapport favorable de la part de M. Pouillet. Ce rapport est dans son genre un petit chef-d'œuvre, et il vaut à lui seul tout un traité de télégraphie électrique'. L. Foucault, 'Académie des sciences', Journal des débats politiques et littéraires, Feuilleton, 15 mai 1850; W. Siemens, 'Mémoire sur la télégraphe électrique', Comptes rendus (1850), 30, 434-7.
}

Deine Messung der Geschwindigkeit des Nevenprincips ist in der Akademie verhöhnt worden; ich trug sie, als Pendant zum Foucaultschen Versuch, sofort nach diesem in der Philomatique vor, aber obschon 
The commission's report was written by Pouillet and, to his credit, he reviewed du Bois-Reymond's findings with great care. ${ }^{138}$ The laws of muscle and nerve currents, the proportionality of muscle current to contraction, the negative variation in muscles and nerves, the descriptions of tetanus and induced contractions - in short, all du BoisReymond's discoveries - were recognized in full. Pouillet also praised the alacrity, skill and cooperativeness with which du Bois-Reymond demonstrated his experiments to the Academy and emphasized the magnitude of du Bois-Reymond's achievement over the last seven years. In Pouillet's opinion, 'one will easily comprehend all the zeal, wisdom and profound thought needed to push so far in this practically new field, where it has been necessary to create in some way the observational tools, experimental protocols and experiments themselves'. ${ }^{139}$

$\mathrm{Du}$ Bois-Reymond's most recent experiment, however, remained an object of controversy. No one doubted the deflection of the galvanometer needle; the real question was, did this deflection indicate the generation of an electric current in muscles experiencing contraction? Until the nature of animal electricity was understood, the answer remained uncertain. Matteucci's experiments with a battery of frog's thighs suggested an external, Voltaic explanation of the current observed. On the other hand, du Bois-Reymond's experiments with nerves suggested an internal, Galvanic mechanism of animal electricity. Most of the commission favoured du Bois-Reymond's rendering, but they emphasized that further research would be necessary to resolve the issue. Even assuming du Bois-Reymond to be correct, no one could say whether the origin of the currents in question was due to an internal chemical action or to the structure of tissues subject to particular forces. Animal electricity, like all phenomena of life, could not be explained by chemistry alone. Furthermore, du Bois-Reymond had only established his laws in muscles and nerves isolated from their natural environments. How could he be sure that 'the cuts of his scalpel were without influence?' ${ }^{140}$ Perhaps mutilation had altered the characteristics of tissue in such a way as to account for the phenomena observed. Only after du Bois-Reymond had experimented on intact systems of muscles and nerves could his suppositions be considered proven. Pouillet encouraged du Bois-Reymond to continue his investigations, congratulated him on his success so far and thanked him on behalf of the Academy.

Du Bois-Reymond left Paris on Tuesday, 21 May 1850, the day after his last meeting with the commission. Racing home, he arrived in Berlin on Thursday. ${ }^{141}$

niemand etwas öffentlich einzuwenden wagte, wurde ich doch im Stillen mit den dümmsten Zweifeln und Einwürfen geplagt.

Emil du Bois-Reymond to Hermann Helmholtz, 25 August 1850, op. cit. (120), 100; 'They consider Helmholtz to be a madman'. Emil du Bois-Reymond to Carl Ludwig, 9 April 1850, op. cit. (45), 57-8, 58.

138 Pouillet et al., op. cit. (134).

139 'On comprendra sans peine tout ce qu'il a fallu de zèle, de sagacité, de profondes méditations pour pénétrer aussi avant dans un sujet presque neuf, où il fallait en quelque sorte créer les moyens d'observations, les procédés d'expérience et les expériences elles-mèmes'. Pouillet, op. cit. (134), 37.

140 'Mais les coups du scapel sont-ils sans influence?' Pouillet, op. cit. (134), 44.

141 Travel diary; E. du Bois-Reymond to Eduard Hallmann, 11 November 1850, op. cit. (1), 133. 
He wrote,

If I saw little of Paris's sights, I did get to know its scientific life extremely well, and having come in disdain, I left in disgust. The amazing thing was that a day did not go by without one of these fellows, great or small, saying to me, 'Oh, you're quite advanced where you live, and we, we just keep bumbling along.' And I told them, 'That comes from not learning German.'

'Ah, yes, but your language is so hard!'142

\section{Conclusion: a strange story}

Twelve years after du Bois-Reymond's trip to Paris Sir Edward Bulwer Lytton published A Strange Story, a novel that appeared serially in both Harper's Weekly and All the Year Round, a magazine run by Charles Dickens. Critics now remember Lytton primarily through an eponymous contest of convoluted style, but contemporary readers enjoyed his gothic tales, many of which featured themes of science. What set A Strange Story apart from similar Victorian fiction was the degree of attention focused on du Bois-Reymond. In Chapter 24 the novel's narrator, a physician-physiologist named Allen Fenwick, recalled the execution and import of du Bois-Reymond's famous experiment:

... I re-entered my study, and was soon absorbed in the examination of that now well-known machine, which was then, to me at least, a novelty - invented, if I remember right, by Monsieur Dubois Reymond, so distinguished by his researches into the mysteries of organic electricity. It is a wooden cylinder fixed against the edge of a table; on the table two vessels filled with salt and water are so placed that, as you close your hands on the cylinder, the forefinger of each hand can drop into the water; each of the vessels has a metallic plate, and communicates by wires with a galvanometer with its needle. Now the theory is, that if you clutch the cylinder firmly with the right hand, leaving the left perfectly passive, the needle in the galvanometer will move from west to south; if, in like manner, you exert the left arm, leaving the right arm passive, the needle will deflect from west to north. Hence, it is argued that the electric current is induced through the agency of the nervous system, and that as human Will produces the muscular contraction requisite, so is it human Will that causes the deflection of the needle. I imagined that if this theory were substantiated by experiment, the discovery might lead to some sublime and unconjectured secrets of science. For human Will, thus actively effective on the electric current, and all matter, animate or inanimate, having more or less of electricity, a vast field became opened to conjecture. ${ }^{143}$

142 Si j'ai peu vu ce qu'à Paris recherchent le plus grand nombre de touristes, j'ai en révanche appris à connaître très-particulièrement la vie scientifique et je m'en retourne avec dégoût, après y être venu avec mépris. Ce qu'il y a de fameux c'est qu'il ne se passe pas un jour où l'un de ses mâtins, gros ou petits, ne me dise: 'Oh, vous êtes bien avancés chez vous, et nous, nous allons toujours en dégringolant'. Je leur dis: 'Cela vient de ce que vous n'apprenez pas l'allemand'. - 'Eh oui, mais votre langue est si difficile!

Emil du Bois-Reymond to his family, 7 mai 1850, Dep. 5, K. 11, Nr. 5. 'With a few exceptions, French scientists in the nineteenth century paid much more attention to what was published in French than in other languages'. M. Crosland, Science under Control: The French Academy of Sciences 1795-1914, Cambridge, New York, 1992, 13.

143 Sir E. Bulwer Lytton, 'A strange story', Harper's Weekly, October 5, 1861, 638. See R. A. Zipser, Edward Bulwer-Lyton and Germany, Berne, Frankfurt am Main, 1974. 
Lytton seemed to have been aware of all the technical difficulties that attended du Bois-Reymond's demonstration. A little later in the chapter, Fenwick is interrupted by an odd character named Margrave:

To gratify him, I sat down and renewed my experiment, with equally ill success. The needle, which should have moved from west to south, describing an angle of from 30 degrees to 40 degrees, only made a few troubled undecided oscillations.

'Tut!' cried the young man, 'I see what it is; you have a wound in your right hand.'

That was true. I had burned my hand a few days before in a chemical experiment, and the sore had not healed.

'Well', said I, 'and what does that matter?'

'Every thing; the least scratch in the skin of the hand produces chemical actions on the electric current, independently of your will. Let me try.'

He took my place, and in a moment the needle in the galvanometer responded to his grasp on the cylinder, exactly as the French philosopher had stated to be the due result of the experiment.

I was startled.

'But how came you, Mr. Margrave, to be so well acquainted with a scientific process little known, and but recently discovered?'

'I well acquainted! not so. But I am fond of all experiments that relate to animal life. Electricity especially is full of interest.' ${ }^{144}$

Lytton's tale shows the extent to which du Bois-Reymond's Parisian experiment excited contemporary imagination. In little over a decade news of his discovery had spread from Berlin to Paris to London to New York, diffusing all the while from the dry reports of scientific societies to the purple prose of the popular press. ${ }^{145}$ Such belated success renders all the more sharp du Bois-Reymond's disappointment in the spring of 1850. If anything, his trip only served to distance him from his French colleagues. Parisian elegance lost its sparkle, hospitality gave way to mistrust, and men he once thought great dwindled to petty figures, vain and condescending. Disgusted with the character of French scientists, he remarked to Helmholtz, 'You really cannot conceive of their mixture of stupidity, arrogance, ignorance and despicability. ${ }^{146}$

Even so, du Bois-Reymond seems to have taken French criticisms quite seriously. As 'a point of honour' he spent nearly a year investigating every foreign objection to his experiment. ${ }^{147}$ To rule out the effects of perspiration, he placed gutta percha bags over

144 Bulwer Lytton, op. cit. (143).

145 See, for example, J. O. N. Rutter, Human Electricity: The Means of its Development, Illustrated by Experiments, London, 1854, especially 127:

It was noticed by Du Bois-Reymond that abrasion of the skin, or a slight wound, on either hand, caused a difference in the force of the current; that proceeding from the wounded hand being the most powerful. This I have frequently verified; a scratch, or chap, on the hand, and forgotten by the operator, having in this way been detected.

146 'Überhaupt hat man von diesem Gemisch von Dummheit, Anmaßung, Unwissenheit und Niederträchtigkeit bei uns gar keinen Begriff'. Emil du Bois-Reymond to Hermann Helmholtz, Berlin, 25 August 1850, op. cit. (120), 100. Helmholtz agreed. Hermann Helmholtz to Emil du Bois-Reymond, 17 September 1850, op. cit. (120), 104-6, 105.

147 Emil du Bois-Reymond to Hermann Helmholtz, April 1852, 3 August 1852, op. cit. (120), 128-30, 129; 135-7, 136; Emil du Bois-Reymond to Henry Bence Jones, Berlin, 23.6.1852, [\#6], SD 3k 1852 (4) (subsequently HBJ), Bl. 7-9; E. du Bois-Reymond, 'Elektrophysiologie', Fortschritte der Physik im Jahre 
his forearms. To rule out the effects of hyperaemia, he tied tourniquets around his index fingers. And to rule out the effects of skin resistance, he stopped at nothing. First he sliced open his fingertips; when this did not expose enough dermis, he applied cantharides, or Spanish fly, to the backs of his wrists. Like the narrator in Lytton's story, large, oval blisters formed on his skin; these he cut away with a scalpel. An assistant then secured short elliptical tubes, or 'wrist vessels', over his injuries with lengths of canvass bandage. Siphons closed the electrical connection to the galvanometer's deriving vessels. The pain of saturated saline on his raw flesh, however, proved too much for him to bear. He diluted the electrolyte filling the wrist vessels and was able to perform the experiment. After a few weeks his wounds healed, at which point he went so far as to repeat the whole procedure. New blisters confirmed his previous trials, and on 13 April 1852 he reported drily to his English friend Henry Bence Jones,

The investigation about the skin currents and the well-known muscular experiment I have now closed at last and the latter has invariably stood any proof to which I have submitted it. Of these proofs there were some of a most trying and severe character and I do not think that my most implacable enemies in Paris would have devised such cross-experiments. ${ }^{148}$

The question arises, why did du Bois-Reymond's committee have so much difficulty accepting his findings? In many respects, the disagreement seems to have come down to an issue of scientific style. Looking back on his experience in 1869, du Bois-Reymond reproved his rivals:

For the last twenty years Germany physiology has been understood, handled and taught as the physics and chemistry of life, and physiologists consider themselves physicists and chemists who merely work in a particular avenue. In France, on the contrary, physiology still cannot raise itself out of the fog of a shameful vitalism. ${ }^{149}$

1848 (1852), 4, 301-29; du Bois-Reymond, op. cit. (6), ii.ii, 357-74; Emil du Bois-Reymond to Carl Ludwig, 17 February 1852, op. cit. (45), 71-3, 71.

148 Emil du Bois-Reymond to Henry Bence Jones, Berlin, 13.4.1852, [\#3], HBJ, Bl. 3-5. Hans Lehmann, 'Über den Willkürversuch du Bois-Reymonds', Pflügers Archiv für die gesammte Physiologie des Menschen und der Tiere (1925), 207, 316-19, argues that du Bois-Reymond eliminated Becquerel's objection with this procedure.

149 The passage reads in full,

In Deutschland wird seit zwanzig Jahren die Physiologie nur noch als Physik und Chemie der Lebewesen aufgefaßt, bearbeitet, gelehrt, und die Physiologen fühlen sich als Physiker und Chemiker, die nur nach einer besonderen Richtung hin arbeiten. Dagegen vermag in Frankreich die Physiologie noch immer nicht sich über die Nebel eines wenn auch verschämten Vitalismus zu erheben; sie hat die von der reinen Physik und Chemie ausgegangene Wandlung nicht durchgemacht, durch welche sie bei uns der Idee nach die letzte Stufe erklomm; ihre Jünger halten sich für etwas ganz anderes als nur für Physiker und Chemiker eigener Art; und vielfach wird sie noch von niederen praktischen Gesichtspunkten aus getrieben, da doch in der Medizin wie in der Technik der beste Weg zu praktisch wichtigen Entdeckungen darin besteht, unbekümmert um den möglichen Nutzen neue Wabrheiten ans Licht zu ziehen.

E. du Bois-Reymond, 'Über Universitätseinrichtungen. In der Aula der Berliner Universität am 15. Oktober 1869 gehaltene Rektoratsrede', in Reden, 2 vols., Leipzig, 1912, i, 356-69, 362. Nine years later he added, 'Nur in gewissem Sinn ist es nicht sinnlos, von einer französischen oder deutschen Physik oder Chemie zu reden'. E. du Bois-Reymond, 'Über das Nationalgefühl. In der Sitzung der Akademie der Wissenschaften zu Geburtstagsfeier des Kaisers und Königs am 28. März 1878 gehaltene Rede', in Reden, op. cit., i, 654-77, 670-1. 
This surely overstates the case. Since mid-century French scientists had pursued a variety of physiological investigations of organ function and the nervous system, and before that, Henri Dutrochet's studies of diffusion had assisted du Bois-Reymond's own entrée into biophysics. ${ }^{150}$ Nevertheless, divorced of disparagement, du Bois-Reymond's characterization rings true. For the most part, French physiology was organicist in conception and, as such, inimical to his entire project. ${ }^{151}$ There were few proofs he could offer for the mechanical function of the body; as Paul Elliott and Andrew Mendelsohn have suggested, French biologists tended to view life in images borrowed from agriculture and medicine. ${ }^{152}$ Though this perspective was reasonable enough, it did blind French scientists to German innovation. It took them at least a generation to appreciate the significance of physiological instruments. ${ }^{153}$ Even as late as 1880 , Charles Richet complained that French laboratories still lagged behind the Dutch and the Germans in the practice of electrophysiology. ${ }^{154}$

The French also had difficulty recognizing the claims of outsiders. ${ }^{155}$ French science centred on a few prestigious institutions in the capital; it was nearly as difficult for Claude Bernard to gain notice as it was for Emil du Bois-Reymond. ${ }^{156}$ The Academy of

150 E. Gley, 'La Société de biologie et l'évolution des sciences biologiques en France de 1849 à 1900', in Essais de philosophie et d'histoire de la biologie, Paris, 1900, 168-312, 216-68. On 9 August 1841 du BoisReymond quoted Dutrochet: 'Plus on avancera dans la connaissance de la physiologie, plus on aura des motifs pour cesser de croire que les phénomènes de la vie sont essentiellement différents des phénomènes physiques'. Emil du Bois-Reymond to Eduard Hallmann, 9 August 1841, op. cit. (1), 94-100, 98, originally in R. Dutrochet, 'Nouvelles observations sur l'endosmose et l'exosmose, et sur la cause de ce double phénomène', Annales de chimie et de physique (1827), 35, 393-400, 400; also cited in J. V. Pickstone, 'Vital actions and organic physics: Henri Dutrochet and French physiology during the 1820s', Bulletin of the History of Medicine (1976), 50, 191-212, 211 n. 63. Pickstone discusses the causes of Dutrochet's neglect in France in 'Locating Dutrochet', BJHS (1978), 11, 49-64.

151 O. Temkin, 'Materialism in French and German physiology in the early nineteenth century', Bulletin of the History of Medicine and Allied Sciences (1946), 20, 322-7, reprinted in The Double Face of Janus and Other Essays in the History of Medicine, Baltimore; London, 1977, 340-4; T. Hall, Ideas of Life and Matter, Chicago, 1969; G. Canguillem, A Vital Rationalist: Selected Writings (ed. F. Delaporte, tr. A. Goldhammer), New York, 1994.

152 P. Elliott, 'Vivisection and the emergence of experimental physiology in nineteenth-century France', in Vivisection in Historical Perspective (ed. N. A. Rupke), London, New York, Sydney, 1987, 48-77; J. A. Mendelsohn, 'Cultures of bacteriology: Formation and transformation of a science in France and Germany, 1870-1914', Ph.D. dissertation, Princeton University, 1996, UMI 9701218. Charles Robin even defined physiology through the language of normal and pathological: 'Nous avons pour but ... en étudiant la physiologie d'arriver à connaître comment les organes peuvent s'altérer et dans quelles limites les fonctions peuvent dévier de l'état normal'. C. Robin, 'Sur la direction que se son proposée en se réunissant les membres fondateurs de la Société de Biologie pour répondre au titre qu'ils ont choisi, Comptes rendus des séances et mémoires de la Société de Biologie (1849), 1, pp. i-xi, read on 7 June 1848, cited in E. Gley, op. cit. (150), 191; G. Canguilhem, The Normal and the Pathological (tr. C. R. Fawcett and R. S. Cohen), New York, 1989.

153 R. G. Frank, 'The telltale heart: physiological instruments, graphic methods, and clinical hopes, 18541914', in The Investigative Enterprise: Experimental Physiology in Nineteenth-Century Medicine (ed. W. Coleman and F. L. Holmes), Berkeley, Los Angeles, London, 1988, 211-90. The Swiss physicist Auguste de la Rive was an exception. Auguste de la Rive to Emil du Bois-Reymond, 7.12.1849, SD B 1840 (1) B1. 14-15.

154 H. W. Paul, The Sorcerer's Apprentice: The French Scientist's Image of German Science, 1840-1919, Gainesville, 1972, 10.

155 'Denn es ist schwer, in Frankreich etwas in ungewöhnlichen Formen bekannt zu machen, die erst von der Nachwelt anerkannt werden'. Jacob Berzelius to Gustav Magnus, 22 Oktober 1833, op. cit. (1), 87-8.

156 Holmes, op. cit. (136), 179-81, 185, 206-9, 295. 
Sciences rarely gave audience to non-members, and they felt that du Bois-Reymond's invitation to present his research was honour enough, particularly at a time when only a tiny fraction of work submitted received any report at all. ${ }^{157}$ As the leading institutional patron of physiology in France, the Academy may well have preferred its own. ${ }^{158}$

Personal differences also seem to have contributed to the disagreement. The first and most obvious was age. Du Bois-Reymond was 31 at the time of his trip; all his referees were in their sixties. This gap in maturity probably stiffened relations. Then there was the issue of character. Despretz was famed for his faith, never a point of attraction for du Bois-Reymond. Pouillet had recently lost a job and two children and most likely his good humour. Du Bois-Reymond's superior instruments had put Becquerel on the defensive as keeper of the Academy's collection. ${ }^{159}$ And Magendie continued to maintain his reputation for insensitivity and arrogance by railing against anaesthesia and denying the contagiousness of cholera. Few contemporaries mistook Balzac's literary dissection of 'le docteur Maugredie, a distinguished intellect, but sceptical and contemptuous, who only believed in the scalpel' ${ }^{160}$

Blame can cut both ways, and some historians have suggested that du BoisReymond's defence of his achievements in Paris bordered on paranoia. Evidence tells against this verdict. Du Bois-Reymond impressed several French scientists, most notably Charles Martins, a naturalist and explorer of Humboldtian stamp who published a favourable review of his work in the popular magazine L'Illustration. ${ }^{161}$ Moreover, du Bois-Reymond's experience in Paris was far from unique. Back in Germany he and his colleagues regaled each other with anecdotes of French impossibility. ${ }^{162}$ As he explained to Helmholtz, 'You did nothing to them; as for me, they have their good reasons. I forced them to slap themselves in the face with their own infallibility; it's right and

157 Holmes, op. cit. (136), 220; M. Crosland, 'The French Academy of Sciences in the nineteenth century', Minerva (1978), 16, 73-102, 79, 91.

158 Elliott, op. cit. (152).

159 Crosland, op. cit. (157), 87.

160 'Un sourire sardonique errait sur les lèvres du troisième, le docteur Mangredie, esprit distingué, mais pyrrhonien et moqueur, qui ne croyait qu'au scalpel'. H. de Balzac, La Peau de chagrin (1831), Paris, 1974, 320-1.

161 C. Martins, 'Expériences de M. Dubois-Reymond sur l'électricité animale', L'Illustration, jounal universel (1850), 15, 383-4. Du Bois-Reymond was also one of the original fourteen German and Austrian correspondents of the Society of Biology. H. W. Paul, From Knowledge to Power: The Rise of the Science Empire in France, 1860-1939, Cambridge, 1985, 62.

162 Speaking of Carlo Matteuci, du Bois-Reymond remarked, 'The headquarters of his operations remains in Paris, that hothouse of quickly blooming notoriety'. E. du Bois-Reymond, 'Elektrophysiologie', Fortschritte der Physik (1847), 3, 392-450, 398. Cf. Alexander von Humboldt to Emil du Bois-Reymond, Potsdam, 25 July 1850 (\#32), op. cit. (7), 108-9; Hermann Helmholtz to Emil du Bois-Reymond, 17 September 1850, op. cit. (120), 104-6, 105; Carl Ludwig to Emil du Bois-Reymond, 10 July 1849, op. cit. (45), 42-3, 43, 19 September 1850, op. cit. (45), 61-3, 63; 'Whoever leaves Paris is soon forgotten there'. H. W. Dove, Gedächtnissrede auf Alexander von Humboldt. Gehalten in der öffentlichen Sitzung der Königl. Preußischen Akademie der Wissenschaften zu Berlin am 1. Juli, dem Leibnitztage des Jahres 1869, Berlin, 1869, 9. Cf. Jacob Berzelius to Gustav Magnus, 4 September 1833; 22 Oktober 1833, op. cit. (1), 84-6, 86; 87-8; W. Haberling, Johannes Müller. Das Leben des rheinischen Naturforschers. Auf Grund neuer Quellen und seine Briefe dargestellt, Leipzig, 1924, 133-6, 219-22. 
just that they'll never forgive me. ${ }^{163}$ Ultimately the Academy's attitudes to du BoisReymond's demonstration seem biased by pride. ${ }^{164}$ As Robert Musil once pointed out, nationalism signifies anxiety more than anything else, and anxiety knows no borders. ${ }^{165}$

If the story of du Bois-Reymond's trip to France has a moral, it is this: distinction is not determination. Relative judgements come easily. No nineteenth-century scientist could mistake the deflection of du Bois-Reymond's galvanometer needle, just as no nineteenth-century scientist could mistake Germany for France. Variations in current and culture are plain. Complexity arises when such differences are claimed as essential. Then, as now, definite pronouncements remain open to doubt.

163 Es amüsiert mich sehr, daß das dumme Geschmeiß in Paris Herrn Bernard und Herrn Budge und Waller mit Preisen überschüttet, aber für Dich nichts - Du hast ihnen doch nichts getan; was mich betrifft, so haben sie ibre guten Gründe. Ich habe sie gezwungen, ibrer eigenen Unfehlbarkeit in's Gesicht zu schlagen; es ist recht und billig, daß sie mir das nie vergessen.

Emil du Bois-Reymond to Hermann Helmholtz, 16 January 1853, op. cit. (120), 138-9, 138.

164 This was recognized by contemporaries. In 1864 Victor Meunier complained,

It is an accepted opinion that the Academy constitutes the central point, to which all discoveries and inventions from the entire world converge as soon as they are made. These discoveries will take the trouble to come to us to verify their authenticity and it is only after being supplied with a passport, signed by us, that they can decently circulate in the republic of science.

V. Meunier, Scènes et types du monde savant, Paris, 1889, 214, quoted in Crosland, op. cit. (142), 369.

165 R. Musil, 'The German as symptom', in Precision and Soul: Essays and Addresses (ed. and tr. B. Pike and D. S. Luft), Chicago, London, 1990, 150-92, 162. 